\title{
Epibenthic megafauna communities in Northeast Greenland vary across coastal, continental shelf and slope habitats
}

\author{
Rosalyn Fredriksen ${ }^{1,2} \cdot$ Jørgen S. Christiansen ${ }^{2,3} \cdot$ Erik Bonsdorff $^{3} \cdot$ Lars-Henrik Larsen $^{1,2} \cdot$ Marie C. Nordström $^{3}$. \\ Irina Zhulay ${ }^{2}$ Bodil A. Bluhm²
}

Received: 5 January 2020 / Revised: 6 August 2020 / Accepted: 11 August 2020 / Published online: 29 August 2020

(c) The Author(s) 2020

\begin{abstract}
The marine area of Northeast Greenland belongs to the largest national park in the world. Biodiversity assessments and tailored conservation measures often target specific physiographic or oceanographic features of an area for which detailed knowledge on their biological communities is incomplete. This study, therefore, characterizes epibenthic megafauna communities in a priori defined seabed habitats (fjord, shelf, shelf break and slope) and their relationship to environmental conditions in Northeast Greenland waters as a basis for conservation and management planning. Megabenthos was sampled from the Bessel Fjord across the shelf to the upper continental slope between latitudes $74.55^{\circ} \mathrm{N}-79.27^{\circ} \mathrm{N}$ and longitudes $5.22^{\circ} \mathrm{W}-21.72^{\circ} \mathrm{W}$ by Campelen and Agassiz trawls at 18 locations (total of 33 samples) at depths between 65 and $1011 \mathrm{~m}$ in August 2015 and September 2017. A total of 276 taxa were identified. Gross estimates of abundance ranged from 4 to 854 individuals $1000 \mathrm{~m}^{-2}$ and biomass ranged from 65 to $528 \mathrm{~g}$ wet weight $1000 \mathrm{~m}^{-2}$ (2017 only). The phyla Arthropoda and Porifera contributed the most to taxon richness, while Mollusca and Echinodermata were the most abundant, and Echinodermata had the highest biomass of all phyla. Fjord, shelf, shelf break and slope seabed habitats revealed different megafaunal communities that were partly explained by gradients in depth, bottom oxygen concentration, temperature, salinity, and turbidity. The present study provides a current baseline of megabenthos across seabed habitats in Northeast Greenlandic waters and reveals putative connections between Arctic and Atlantic biota.
\end{abstract}

Keywords Arctic $\cdot$ Bessel Fjord $\cdot$ Community structure $\cdot$ Environmental drivers $\cdot$ Epibenthic megafauna baseline $\cdot$ Northeast Greenland shelf

\section{Introduction}

The human footprint is in the process of growing immensely in marine areas globally including pan-Arctic shelves (Halpern et al. 2015), given drastic sea ice decline (Stroeve et al.

Electronic supplementary material The online version of this article (https://doi.org/10.1007/s00300-020-02733-z) contains supplementary material, which is available to authorized users.

Bodil A. Bluhm

bodil.bluhm@uit.no

1 Akvaplan-niva, The Fram Centre, Hjalmar Johansens Gate 14, 9007 Troms $\varnothing$, Norway

2 Department of Arctic and Marine Biology, UiT-The Arctic University of Norway, 9037 Troms $\varnothing$, Norway

3 Environmental and Marine Biology, Åbo Akademi University, 20520 Turku, Finland
2012) now allows easier access. Implementing protective conservation measures for marine areas moves at a much slower pace and large knowledge gaps often hinder efficient and targeted measures. The marine area of Northeast Greenland belongs to the largest national park in the world containing pristine fjords and productive polynyas that support marine wildlife (Ambrose and Renaud 1995; Aastrup and Boertmann 2009). Although part of that area is covered by landfast ice inshore and pack ice offshore for more than 10 months a year (Christiansen et al. 2016) and despite its protected status, that area, too, is exposed to direct or indirect human impact. Biodiversity assessments and tailored conservation measures need detailed taxa inventories and baselines against which potential impacts of such human activity as well as ocean warming can be evaluated. Such assessments and measures are needed for specific habitats which are often classified by geophysical environmental features (Roff and Taylor 2000; Last et al. 2010; Harris and 
Baker 2020). Following this approach, we characterize seafloor communities in defined habitat types in this study.

Long-lived Arctic benthic invertebrate species, often with limited motility, are useful for habitat characterizations because they provide a time-integrated and site-specific history for a given habitat (Grebmeier et al. 2015). Their composition and abundance may vary with hydrographic conditions such as temperature and salinity, as well as with seafloor properties and food supplies, and these factors may be related to latitude and depth (Mayer and Piepenburg 1996; Bluhm et al. 2009; Buhl-Mortensen et al. 2012; Roy et al. 2014). Therefore, benthic communities are also well-suited to mirror putative changes in oceanography, pelagic-benthic coupling, advection, and effects of human activities, including demersal fisheries, petroleum exploitation and mining (Jørgensen et al. 2015; Ravelo et al. 2015; Christiansen 2017). Epibenthos, those invertebrates living on top of or just above the seafloor, provides an important food source for higher trophic levels (Bluhm and Gradinger 2008) and contributes to recycling of organic matter (Piepenburg et al. 1997a; Ambrose et al. 2001). Nonetheless, these communities with their habitat associations and their links to environmental drivers are poorly known for parts of the marine national park area of Northeast Greenland. The available information to date is partly based on underwater image analyses yielding limited taxonomic and/or regional resolution (e.g. Mayer and Piepenburg 1996; Starmans et al. 1999; Sejr et al. 2000). Expanding the taxonomic and regional characterization of epibenthic communities in northeast Greenland waters is, therefore, the focus of this study.

The national park of Northeast Greenland protects $972,001 \mathrm{~km}^{2}$ of the interior and northeastern coast and shelf of Greenland (Statistics Greenland 2019) and contains a variety of habitat types. Glacial fjords are scattered along the coast and stretch hundreds of kilometers into the mainland, many of them being the largest fjord systems in the northern hemisphere (Funder et al. 1998). High sedimentation rates and turbidity characterize these fjords (Görlich et al. 1987; Syvitski et al. 1989; Ashley and Smith 2000), and such fjordic conditions often result in differences in benthic communities from regions outside fjords (Holte and Gulliksen 1998; Włodarska-Kowalczuk et al. 2005, 2012). Adjacent to these fjords, the Northeast Greenland shelf extends more than $300 \mathrm{~km}$ seawards from the coastline (Arndt et al. 2015). Seabed features include fjord basins separated by sills and submarine canyons that extend from the fjords towards the shelf creating banks and troughs (Laberg et al. 2017). The Northeast Greenland coast and shelf are dominated by the outflow of subzero temperature waters and sea ice from the Arctic Basin (Michel et al. 2015) that pass through the western Fram Strait, driven by the Transpolar Drift (Kwok 2008) (Fig. 1). These Arctic water masses form the cold southbound East Greenland Current (EGC) on the Northeast Greenland shelf (Hopkins 1991; Sejr et al. 2017). Landwards, the EGC meets freshwater from the accelerating melt of the Greenland ice sheet which also enriches the Northeast Greenlandic fjords and coastal areas with terrigenous sediments (Khan et al. 2014; Sejr et al. 2017). Further east, the Northeast Greenland shelf break is distinct from the shelf as the ambient environment here meets branches of warmer and more saline Atlantic water coming from the West Spitzbergen Current (WSC) (Håvik et al. 2017). Parts of the Atlantic Waters from the WSC recirculate and flow southwards along the East Greenland Shelf where they converge with the EGC along the Northeast Greenland shelf break and slope (Schneider and Budéus 1997; Christiansen et al. 2016) (Fig. 1) and diverge as the Return Atlantic Current (RAC) (Paquette et al. 1985). Beyond the shelf break, the EGC also transports deep and intermediate waters exiting the Arctic (Rudels et al. 2002). Differences in geomorphology, bathymetry combined with gradients in other environmental conditions and water masses of different origins and properties are, thus, expected to contribute to structuring the local epibenthic communities. In some areas, several recurring polynyas, including the Northeast Water Polynya (Schneider and Budéus 1997), may create strong phytoplankton blooms and subsequent export of organic matter to benthic communities (Ambrose and Renaud 1995; Piepenburg et al. 1997a).

This study characterizes epibenthic seabed communities in geomorphologically and hydrographically distinct habitats as a basis for conservation and management planning. The study includes a glacial and secluded sill fjord (Bessel Fjord), an open bay (Dove Bugt), and offshore locations on the shelf, shelf break and upper slope within the Northeast Greenland National Park. The primary objectives for this study are to (1) contribute to the inventory of epibenthic invertebrates and estimate their taxon richness, gross abundance and biomass, (2) examine differences in epibenthic communities among fjord, shelf, shelf break and slope habitats, and (3) identify environmental variables that explain variations in epibenthic community structure across these seabed habitats.

\section{Materials and methods}

\section{Study area}

Epibenthic megafaunal invertebrates were sampled from R/V Helmer Hanssen (UiT-The Arctic University of Norway, Troms $\varnothing$ ), as part of the ongoing international TUNUProgramme (TUNU means East Greenland in Greenlandic), an effort focused on fish diversity and adaptation (Christiansen 2012), during the TUNU-VI Expedition in August 2015 and the TUNU-VII Expedition in September 2017. For those 


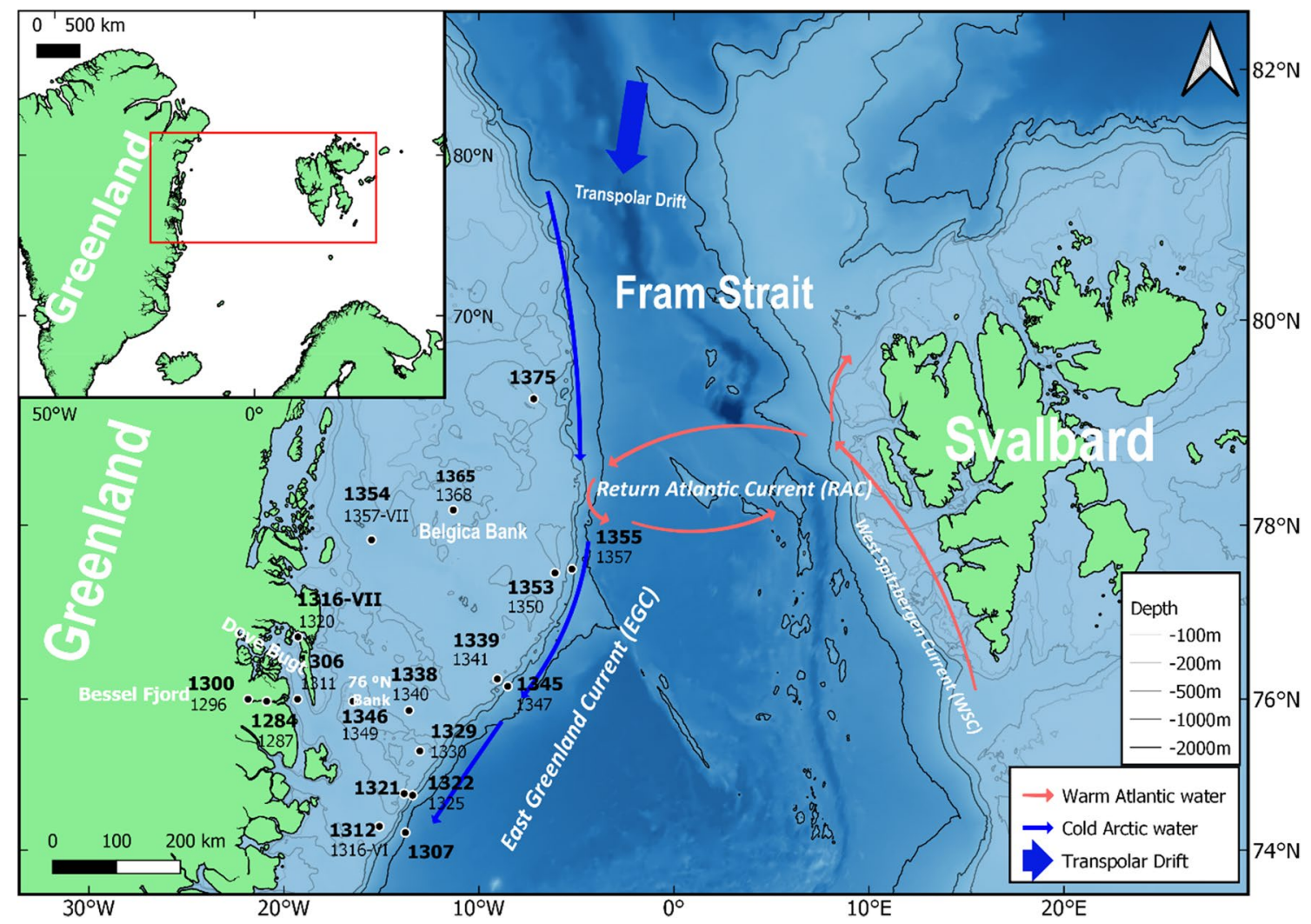

Fig. 1 Map of the epibenthic stations sampled during TUNU-VI and TUNU-VII expeditions to Northeast Greenland in 2015 and 2017, respectively. This map shows both Campelen and Agassiz trawl stations, which were mostly deployed at the same locations. Campelen stations are highlighted in bold text. Major ocean currents that are influencing the study area are also shown, The Transpolar Drift, East
Greenland Current (EGC), Return Atlantic Current (RAC) and West Spitzbergen Current (WSC). Modified from Paquette et al. (1985), Carmack and Wassmann (2006) and Bluhm et al. (2015). Cold Arctic waters are shown as blue arrows and warm Atlantic waters are shown as red arrows

Some hyperbenthic and near bottom-pelagic taxa occur consistently in the benthic boundary layer (Themisto libellula: Vinogradov (1999) and Hirche et al. (2016); Gonatus fabricii: Bjørke and Gjøsæter (1998)) and were, therefore, not excluded from the data analysis. Biomass estimates were only done for the TUNU-VII samples. The Campelen trawl had an opening width of $11.7 \mathrm{~m}$ and was rigged with a $35.6 \mathrm{~m}$ rock-hopper gear with rubber disks of $356 \mathrm{~mm}$ diameter. The mesh size decreased from $80 \mathrm{~mm}$ in the wings to $40 \mathrm{~mm}$ in the cod end (Walsh and McCallum 1997). This arrangement allows retention of larger epibenthic invertebrates with minimum size often smaller than the mesh size (often to ca. $1 \mathrm{~cm}$ ) when the mesh is stretched. The towing speed was approximately 3 knots, and the duration of deployments at the bottom varied between 10 and $29 \mathrm{~min}$ as recorded by a SCANMAR sensor attached to the trawl. The Agassiz and Campelen trawl samples combined provided information on taxon richness at given locations. While generally better suited to catch benthic taxa, the Agassiz trawl is considered a qualitative sampling gear (Eleftheriou and MacIntyre 2005) and was hence not used for abundance we, therefore, refer to the fauna as megafaunal invertebrates. 


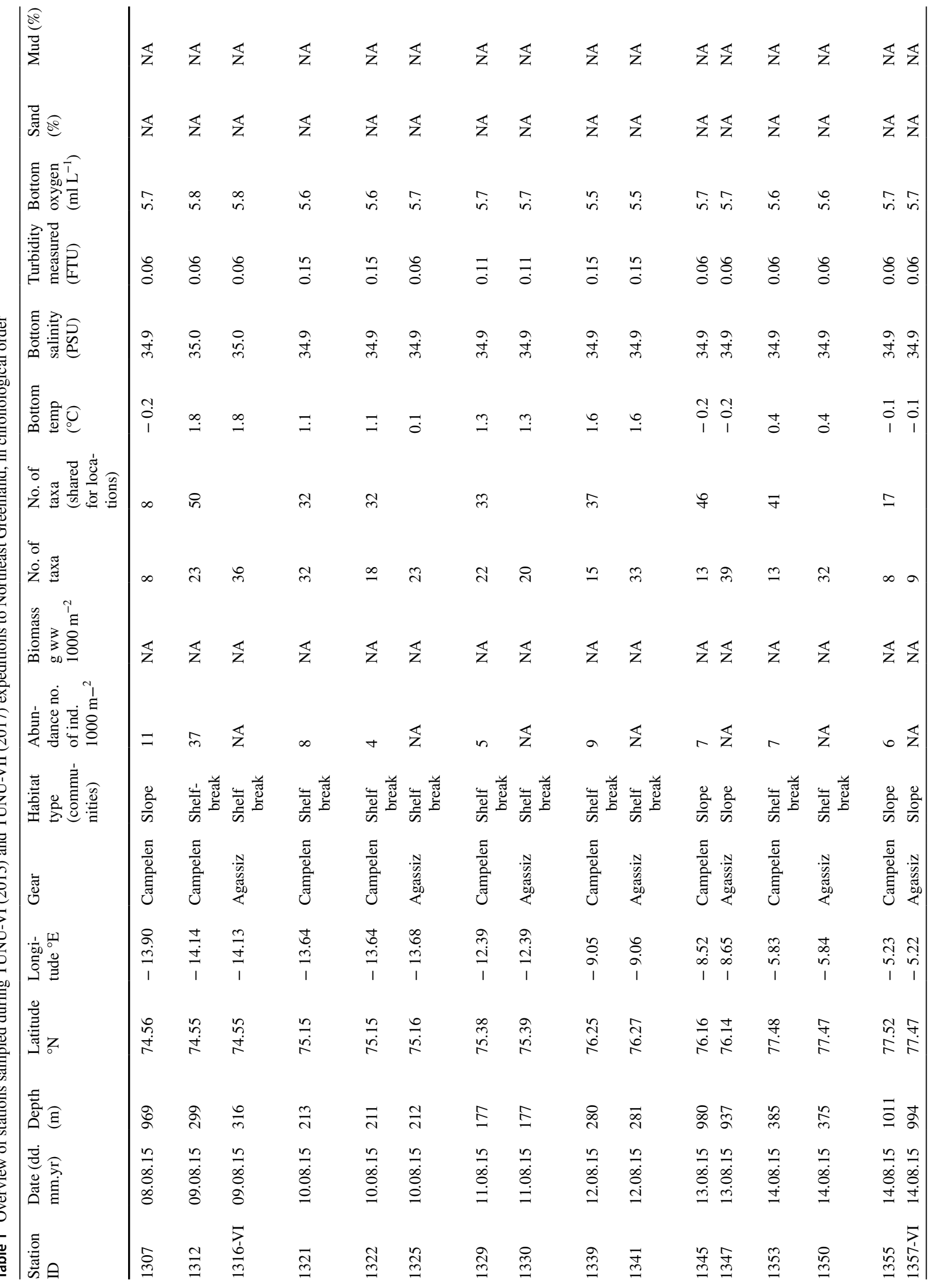




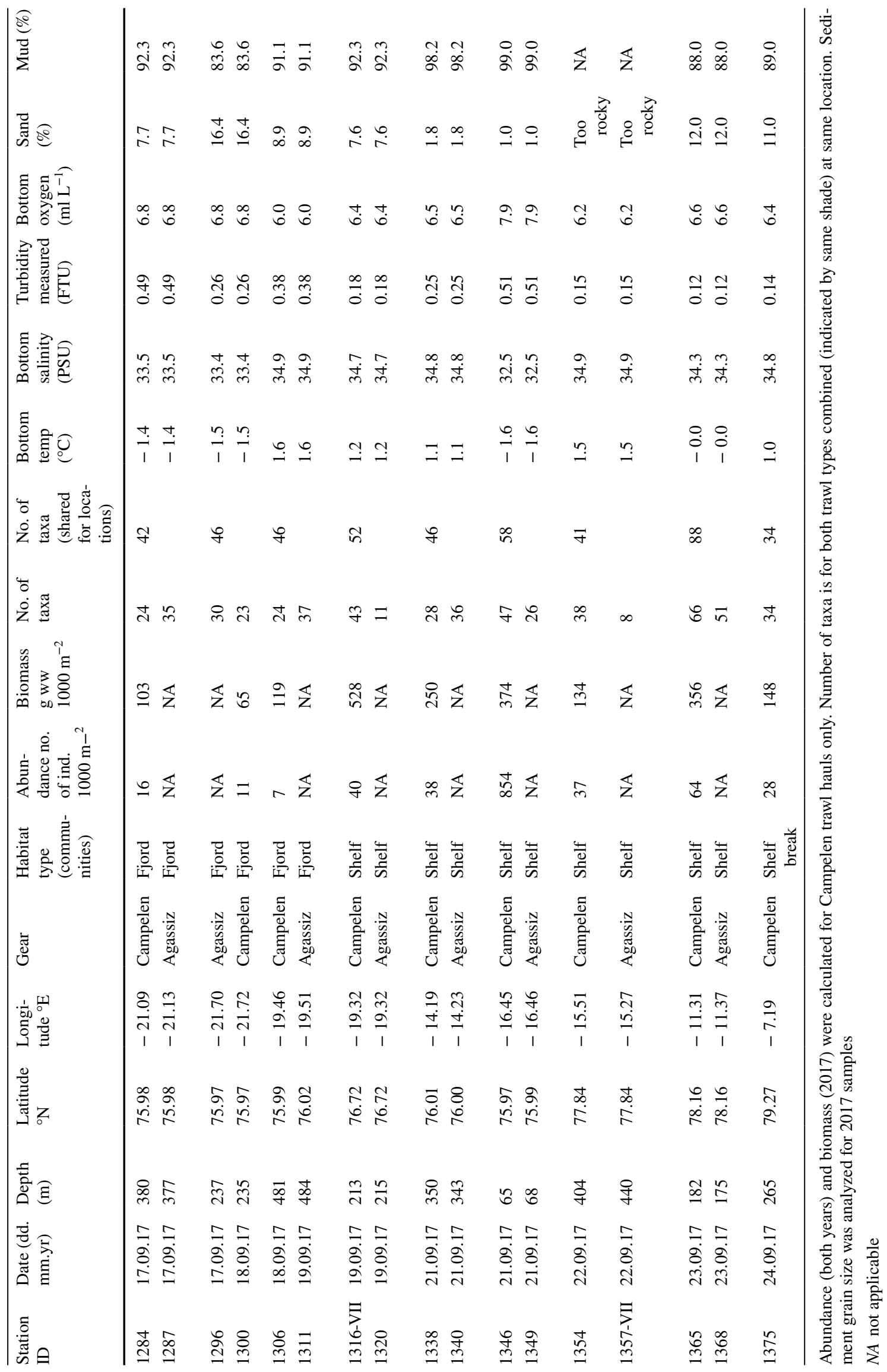


and biomass estimates. The Agassiz trawl had a fixed frame $(1.80 \times 0.47 \mathrm{~m})$ with a uniform net mesh size of $80 \times 80 \mathrm{~mm}$. Towing speed varied from 0.7 to 3.7 knots with an estimated duration of 9-40 min bottom time. Campelen (18 samples) and Agassiz (15 samples) trawls were deployed consecutively at a given location (i.e. at roughly the same geographic position); each individual trawl sample was assigned a unique identifier (Fig. 1, Table 1).

For both trawl types, the entire sample was sorted and examined once the trawl hauls were on deck. Epibenthic invertebrates were collected and sorted to the lowest possible taxonomic level. Taxa were identified either onboard or in the university laboratory using Sirenko (2004), Vassilenko and Petryashev (2009), Buzhinskaja (2010), Stepanjants (2012) among other sources. Individuals for each identified taxon were then enumerated for abundance and composition estimates, and the respective weight ( $\mathrm{g}$ wet weight, ww) was measured using a Marel M2200 $(<200 \mathrm{~g})$ and commercial fish scales $(>200 \mathrm{~g}$ ) onboard. For colonial organisms such as Bryozoa, Hydrozoa and Porifera, only weight was recorded given that individuals cannot be enumerated.

Voucher specimens were preserved in a buffered $4 \%$ seawater-formaldehyde solution onboard and were later transferred to $70 \%$ ethanol for long-term storage and distribution among experts (see acknowledgements) for taxonomic validation. The low taxonomic resolution achieved for Brachiopoda, Bryozoa, Cephaloryncha, Cnidaria, Nemertea, part of Porifera and Sipuncula made it more appropriate to use the term 'taxon richness' rather than 'species richness' in the remainder of this article. Because the field teams differed between the two TUNU expeditions, some epibenthic invertebrates were not consistently identified and were, therefore, grouped at higher taxonomic rank, e.g., the species-rich gastropod genera Colus and Buccinum, and some Amphipoda. Taxa names follow the current nomenclature in the World Register of Marine Species (WoRMS) using the taxon match tool (https://www.marinespecies.org/aphia.php? $\mathrm{p}=$ match; www.marinespecies.org: [Accessed: 06.12.2019]).

\section{Environmental variables and habitat categories}

The following environmental variables were recorded at each location: near-bottom temperature and salinity, oxygen concentration, turbidity, and depth and latitude. Furthermore, sediment grain size was examined at TUNU-VII stations (Table 1). Temperature, salinity, oxygen concentration and turbidity were recorded by a Sea-Bird Electronics SBE-911 conductivity-temperature-depth (CTD) profiler. Sediments were sampled by a box corer, and the grain size composition for given locations was used as a proxy for ambient current velocity. A coarse seabed, however, prevented sediment sampling at some locations (Table 1). Grain size distribution was analyzed with a Beckman Coulter Particle Size analyzer LS 13320 at the Department of Geosciences, UiT.

Sampling locations were grouped into four habitat categories based on geomorphological and hydrographic features from multibeam surveys during the cruise and from the IBCAO bathymetry (Jakobsson et al. 2012). Fjords are characterized as underwater valleys with steep walls carved by glacial activity, and usually comprising one or several sediment-collecting basins separated by sills (Howe et al. 2010). The shelf is defined as the area offshore of the coast and to the shelf break and with relatively low angles in bathymetry, while the shelf break has an angle typically larger than 4 degrees which is generally at depths of ca. 200-400 m in Northeast Greenland (Jakobsson et al. 2012). The upper continental slope is below the shelf break and is the steeply sloping part of the continental margin extending to the continental rise where the angle drops to below $1^{\circ} 25^{\prime}$ (Hay 2016).

\section{Data analyses}

The Campelen trawl was equipped with SCANMAR sensors which continuously monitored bottom contact allowing approximate calculations of swept area by multiplying the trawling distance with the mean width of the trawl opening $(11.7 \mathrm{~m})$. For Campelen trawl samples, abundance and biomass estimates were then standardized to number of individuals (ind.) and gram wet weight (g ww) $1000 \mathrm{~m}^{-2}$, respectively, acknowledging that the proportion of water and inorganic matter differs considerably among epibenthic taxa, and therefore wet weight provides only a gross estimate of available energy (Brey 2001; Brey et al. 2010). Separately for both trawl types, the most widely distributed taxa were identified by calculating the frequency of occurrence (FO) as the proportion of locations where a given taxon occurred. For taxon richness, trawl samples from both catches were combined from a given location. Taxon richness, abundance and biomass were mapped with QGIS 3.12.2 and IBCAO v.3 (Jakobsson et al. 2012) and Jenks natural breaks function for scaled circles. Land- and coastline polygons in addition to depth contour information for mapping were downloaded from www.naturalearthdata.com.

Multivariate analyses of community composition from the Campelen trawl samples were performed in the statistical software program PRIMER v. 7.0.13. Given that proportional abundances differed moderately and significantly between Campelen and Agassiz trawl samples (ANOSIM, global $R=0.18, p=0.007$ ) further community analyses were conducted for Campelen trawl samples only. A fourth-root transformation of abundance data was applied to reduce the impact of numerically dominant species and to balance the importance of rare taxa (Field et al. 1982; Clarke and Warwick 2001; Johnson and Barmuta 2015). 
Transformed abundance data were then used to compute a Bray-Curtis similarity matrix (Bray and Curtis 1957), station similarity was then depicted in a non-metric multidimensional scaling (nMDS) ordination plot (Kruskal and Wish 1978) and in a dendrogram using hierarchical cluster analysis with group average sorting. The SIMPROF routine tested the validity of the clusters in the dendrogram. Potential differences in epifaunal communities among the a priori defined habitat types were tested using Analysis of Similarities (ANOSIM, Clarke and Warwick 2001). Taxa contributing most to community similarity in habitat types were identified using the similarity of percentages routine (SIMPER).

To explore patterns in environmental conditions across the study area we used a Principal Component Analysis (PCA) of the six normalized environmental variables that were available for both sampling years (temperature, salinity, oxygen, turbidity, depth and latitude). To identify the environmental variables that best correlated with the epibenthic community structures, the Biological-Environmental interactions routine (BIO-ENV, Clarke and Gorley 2006) was applied, separately with the six environmental variables common for both sampling years (2015 and 2017), and with the seven variables recorded in 2017.

\section{Results}

\section{Species richness and distribution of taxa}

A total of 276 epibenthic invertebrate taxa (79 of them to species level) were identified from a total of 33 Campelen and Agassiz trawl samples from 18 locations during TUNUVI (2015) and TUNU-VII (2017) (Online Resource 1). The three phyla that contributed the most to the overall taxon richness were Arthropoda with 73 taxa (26\% of all taxa), Porifera with 46 taxa (17\%) and Mollusca with 41 taxa (15\%). Highest taxon richness was recorded on the shelf banks, i.e. Belgica Bank ( 88 taxa; samples 1365 and 1368) and an unnamed bank at latitude $76^{\circ} \mathrm{N}$, hereafter named $76^{\circ} \mathrm{N}$-Bank (58 taxa; samples 1346 and 1349) (Table 1, Fig. 2). In contrast, the two deep locations at the continental slope had the lowest taxon richness with eight taxa (one sample only, 1307; $969 \mathrm{~m}$ ) and 17 taxa (samples 1357; $994 \mathrm{~m}$, and $1355 ; 1011 \mathrm{~m})$. The latter location was the deepest and,

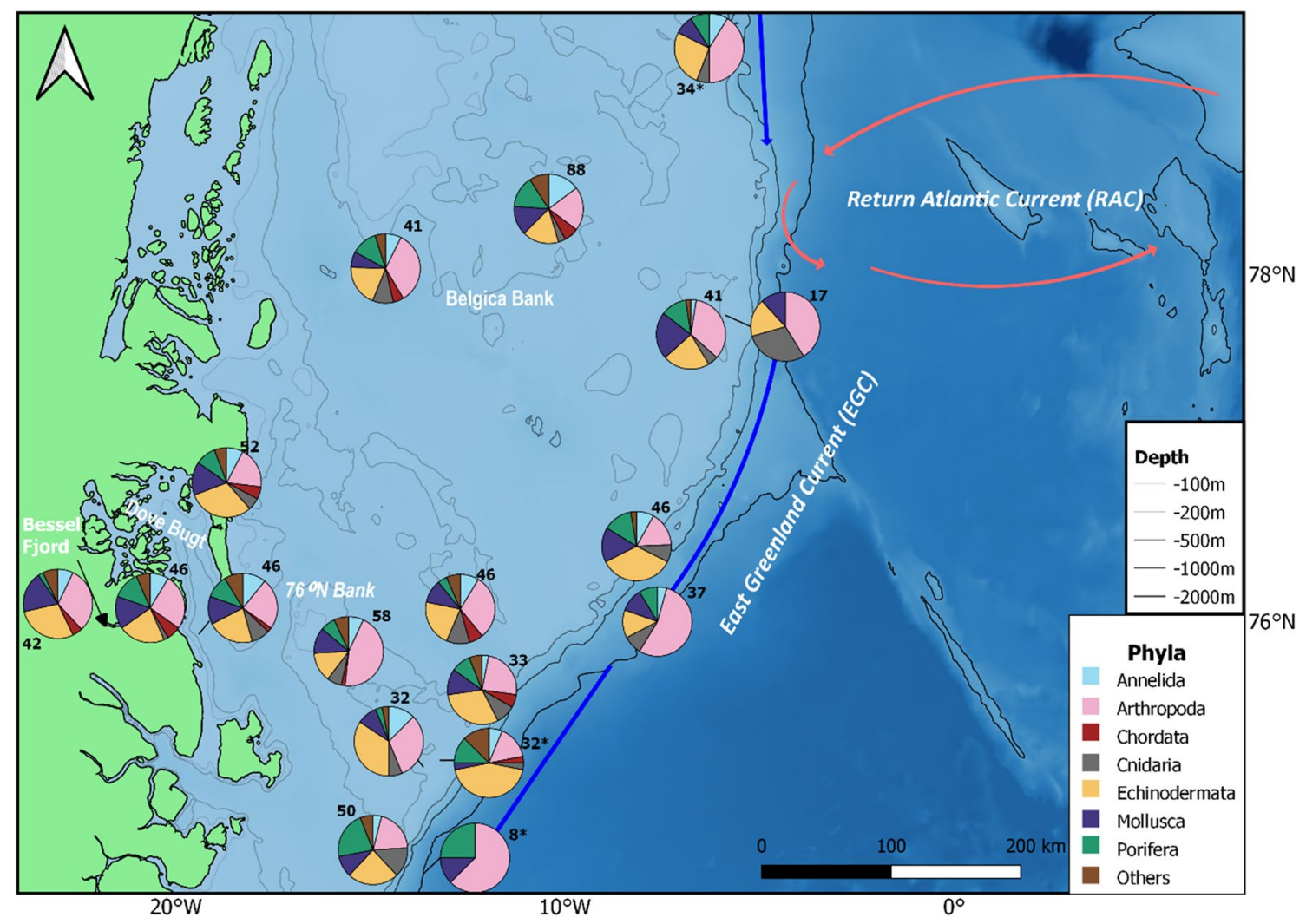

Fig. 2 Taxonomic composition of epibenthic invertebrates at eighteen locations in Northeast Greenland from 33 combined Campelen and Agassiz trawl samples collected during 2015 and 2017. The numbers indicate the total number of taxa per location. Asterisk indicates only Campelen trawl samples were collected at marked locations (three locations with Campelen only) 
interestingly, none of the eight taxa caught in the Campelen overlapped with the nine taxa caught in the Agassiz trawl. The number of taxa in Bessel Fjord was relatively similar from the innermost part of the fjord towards the mouth, though Porifera taxa were fewer at the inner fjord location. The taxa accumulation curves suggest that a higher sampling effort is needed to capture the full epibenthic inventory of Northeast Greenland given no asymptote was reached for either gear type (Fig. 3). Moreover, the Agassiz trawl sampled more taxa than the Campelen trawl for some locations.

\section{Frequency of occurrence, abundance and biomass estimates}

The most frequently caught taxa ( $\geq 50 \%$ in all 33 samples) mostly belonged to the phyla Arthropoda and Echinodermata (Table 2). The polar shrimp Lebbeus polaris was present in all Campelen samples, whereas the ophiuroids Ophiacantha bidentata, Ophiopleura borealis and Ophiocten sericeum were present in $\geq 85 \%$ of the Agassiz samples. One cnidarian and one annelid species were also among the top ten most frequently caught taxa in Campelen and Agassiz samples, respectively.

The estimated swept area for the Campelen trawl ranged from an approximately 9,600 to $21,000 \mathrm{~m}^{2}$. The abundance estimates of megafaunal invertebrates ranged across two orders of magnitude from $<12$ ind. $1000 \mathrm{~m}^{-2}$ at more than half of all stations to $>850$ ind. $1000 \mathrm{~m}^{-2}$ at a single shelf station (1346) (Table 1, Fig. 4a). Only at shelf (and one shelf break) stations did estimated abundances exceed 30 ind. $1000 \mathrm{~m}^{-2}$. Maxima occurred at banks which, like most stations, were dominated by a single taxon. The shelf banks were dominated by the bivalve Similipecten greenlandicus at $76^{\circ} \mathrm{N}-\mathrm{B}$ ank and the ophiuroid Ophiopleura borealis at Belgica Bank (Fig. 4b). Abundance estimates in Bessel
Fjord were lower compared to the shelf (Fig. 4b) and were dominated by the ophiuroid Ophiopleura borealis in the inner ford, and the asteroid Ctenodiscus crispatus at the mouth of the fjord. Across the five shelf stations, the most abundant taxa belonged to Echinodermata and Arthropoda. In Dove Bugt (station 1316) the crinoids Heliometra glacialis and Poliometra polixa (Echinodermata) were abundant (Fig. 4b), whereas Arthropoda were abundant at the shelf stations, namely the amphipod Eusirus spp. (station 1354) and the polar shrimp Lebbeus polaris (station 1338). Abundance estimates for the shelf break and slope stations were variable, though lower than at shelf stations, ranging from 4 ind. $1000 \mathrm{~m}^{-2}$ (station 1322) to 37 ind. $1000 \mathrm{~m}^{-2}$ (station 1312). These slope stations were dominated by Arthropoda and Echinodermata and again, single species contributed the most to the total abundance (Fig. 4b). At the shelf break the most abundant taxa were, from south (station $1312,74.55^{\circ}$ $\mathrm{N})$ to north (station $1375,79.27^{\circ} \mathrm{N}$ ), Lebbeus polaris, the pale sea urchin Strongylocentrotus pallidus, the glass shrimp Pasiphaea tarda, the warrior shrimp Sclerocrangon ferox, the squid Gonatus sp. and the sevenlined shrimp Sabinea septemcarinata.

Gross biomass estimates (2017 stations only) ranged from $65 \mathrm{~g} \mathrm{ww} 1000 \mathrm{~m}^{-2}$ at a shelf station (station 1338) to $528 \mathrm{~g}$ ww $1000 \mathrm{~m}^{-2}$ in Dove Bugt (station 1316) (Fig. 4c). In Dove Bugt, large basket stars Gorgonocephalus spp. had high biomass (Fig. 4d). The second highest biomass estimate was for $76^{\circ} \mathrm{N}$-Bank (station 1346) with $374 \mathrm{~g}$ ww $1000 \mathrm{~m}^{-2}$ and was a result of mass occurrence of the bivalve Similipecten greenlandicus. In Bessel Fjord biomass was dominated by the sea cucumber, Molpadia borealis at the two innermost stations and by a Forcepia-like sponge at the mouth. Notably, the deep-sea shrimp Pandalus borealis was abundant at one shelf station (station 1338). The catches of $P$. borealis can be biased by both diel and ontogenetic vertical migration
Fig. 3 Taxa accumulation curve of epibenthic invertebrates in Northeast Greenland from Campelen and Agassiz trawl samples during 2015 and 2017. Shaded areas are confidence intervals for random samples

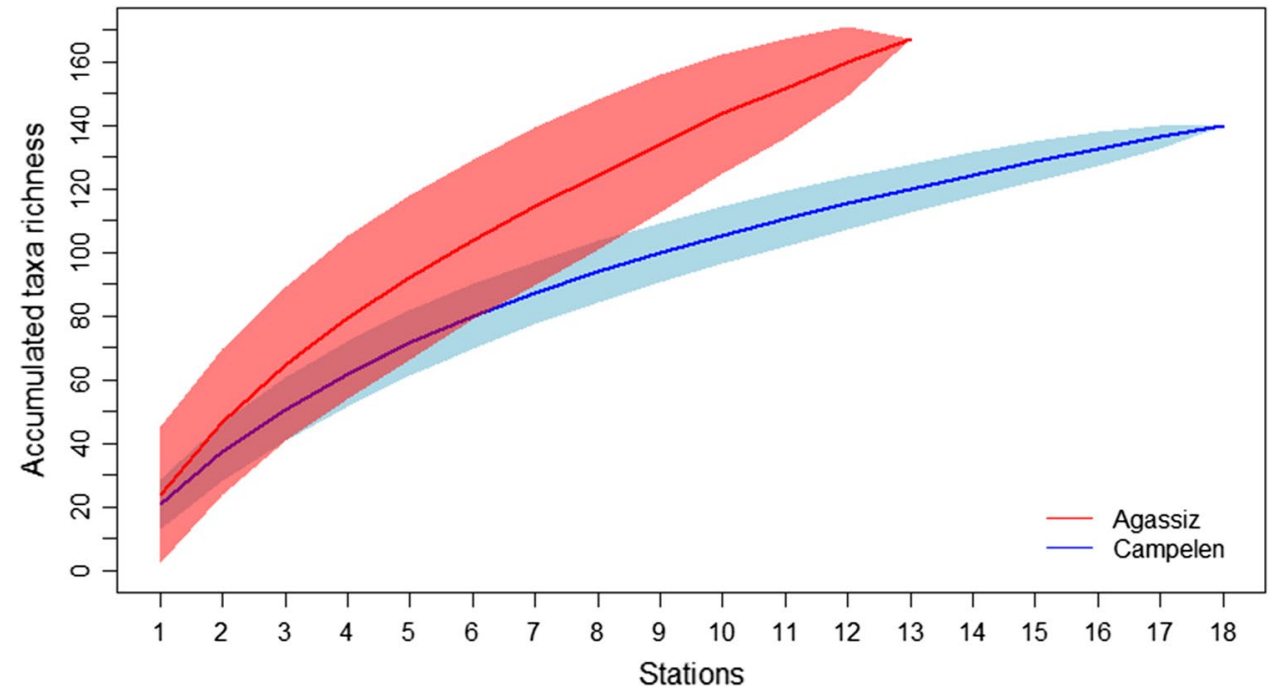


Table 2 The ten most frequently occurring (FO) epibenthic invertebrate taxa during the combined TUNU-VI (2015) and TUNU-VII (2017) expeditions to Northeast Greenland

\begin{tabular}{|c|c|c|c|c|c|}
\hline No & Taxa & Phylum & Class & FO (Campelen) & $\begin{array}{l}\text { FO }(\%) \\
\text { across study } \\
\text { area }\end{array}$ \\
\hline 1 & Lebbeus polaris & Arthropoda & Decapoda & 18 & 100 \\
\hline 2 & Ophiopleura borealis & Echinodermata & Ophiuroidea & 13 & 72 \\
\hline 3 & Sclerocrangon ferox & Arthropoda & Decapoda & 11 & 61 \\
\hline 4 & Anonyx spp. & Arthropoda & Amphipoda & 10 & 56 \\
\hline 5 & Strongylocentrotus pallidus & Echinodermata & Echinoidea & 10 & 56 \\
\hline 6 & Colus spp. & Mollusca & Gastropoda & 10 & 56 \\
\hline 7 & Sabinea septemcarinata & Arthropoda & Decapoda & 9 & 50 \\
\hline 8 & Umbellula encrinus & Cnidaria & Anthozoa & 9 & 50 \\
\hline 9 & Pontaster tenuispinus & Echinodermata & Asteroidea & 9 & 50 \\
\hline 10 & Gorgonocephalus spp. & Echinodermata & Ophiuroidea & 9 & 50 \\
\hline No & Taxa & Phylum & Class & FO (Agassiz) & $\begin{array}{l}\mathrm{FO}(\%) \\
\text { across study } \\
\text { area }\end{array}$ \\
\hline 1 & Ophiacantha bidentata & Echinodermata & Ophiuroidea & 12 & 92 \\
\hline 2 & Ophiopleura borealis & Echinodermata & Ophiuroidea & 11 & 85 \\
\hline 3 & Ophiocten sericeum & Echinodermata & Ophiuroidea & 11 & 85 \\
\hline 4 & Sclerocrangon ferox & Arthropoda & Decapoda & 8 & 62 \\
\hline 5 & Pontaster tenuispinus & Echinodermata & Asteroidea & 8 & 62 \\
\hline 6 & Lebbeus polaris & Arthropoda & Decapoda & 7 & 54 \\
\hline 7 & Colus spp. & Mollusca & Gastropoda & 7 & 54 \\
\hline 8 & Boreonymphon spp. & Arthropoda & Pycnogonida & 7 & 54 \\
\hline 9 & Nothria conchylega & Annelida & Polychaeta & 7 & 54 \\
\hline 10 & Icasterias panopla & Echinodermata & Asteroidea & 7 & 53.8 \\
\hline
\end{tabular}

Top: Campelen trawl (18 samples), bottom: Agassiz trawl hauls (15 samples)

behavior of this species (Barr 1970; Hopkins and Nilssen 1990), but most trawls were conducted during daytime where the shrimp is closer to the bottom. At the single shelf break station from TUNU-VII Expedition in 2017 (station 1375), Sclerocrangon ferox contributed the most to biomass.

\section{Epibenthic community structure}

Clustering yielded six significant clusters which largely reflected the four habitat types (Fig. 5a) with shelf and shelf break stations each forming two clusters; and slope and fjord stations each forming one cluster and stations in each habitat grouping together in the nMDS ordination (Fig. 5b, c). Exception were the northernmost station (station 1375, classified shelf break) and the outermost fjord station which both clustered with shelf stations, though the latter grouped closely with the other fjord stations in the nMDS ordination (Fig. 5b, c). Communities in the four habitat categories were statistically different (one-way ANOSIM, Table 3) with large differences found between all habitat combinations in pairwise comparisons (Table 3). While the low number of stations in fjord and slope habits limited a meaningful statistical comparison, the epibenthic community difference is obvious in the nMDS (Fig. 5b). The average similarity within community groups varied from 37 to $49 \%$ and was highest for slope and lowest for shelf break communities (SIMPER analysis, Table 4). The brittle star Ophiopleura borealis and Lebbeus polaris were typical for fjord, shelf and shelf break, but not for slope communities. In addition, the hyperiid Themisto libellula and the ascideans Styela spp. characterized the fjord community. The shelf communities were also characterized by two pycnogonids (Boreonymphon sp. and Nymphon hirtipes), Sabinea septemcarinata, the two cnidarians Zoantharia and Umbellula encrinus and the amphipods Anonyx spp. In comparison, Sclerocrangon ferox and Strongylocentrotus pallidus were typical of the shelf break community. The squid Gonatus sp. and the Crimson glass shrimp Pasiphaea tarda characterized the slope community. Levels of dissimilarity between 
Fig. 4 Abundance and biomass of epibenthos in Northeast Greenland. a Distribution of epifaunal abundance (ind $1000 \mathrm{~m}^{-2}$ ) from Campelen 1800 shrimp trawl from the TUNU expeditions to Northeast Greenland in 2015 and 2017. Scaled circles of abundance and biomass were adjusted to Jenks natural breaks. b estimated abundance for both years, where the three taxa with highest abundance are shown as images (Similipecten greenlandicus, Ophiopleura borealis and Crinoidea). $\mathbf{c}$ Distribution of biomass (g ww $1000 \mathrm{~m}^{-2}$ ) for epifaunal catches for 2017 only and $\mathbf{d}$ Estimated biomass caught during TUNU-VII (2017), where the three taxa with highest biomass are shown (Gorgonocephalus spp., Similipecten greenlandicus and Ophiopleura borealis)

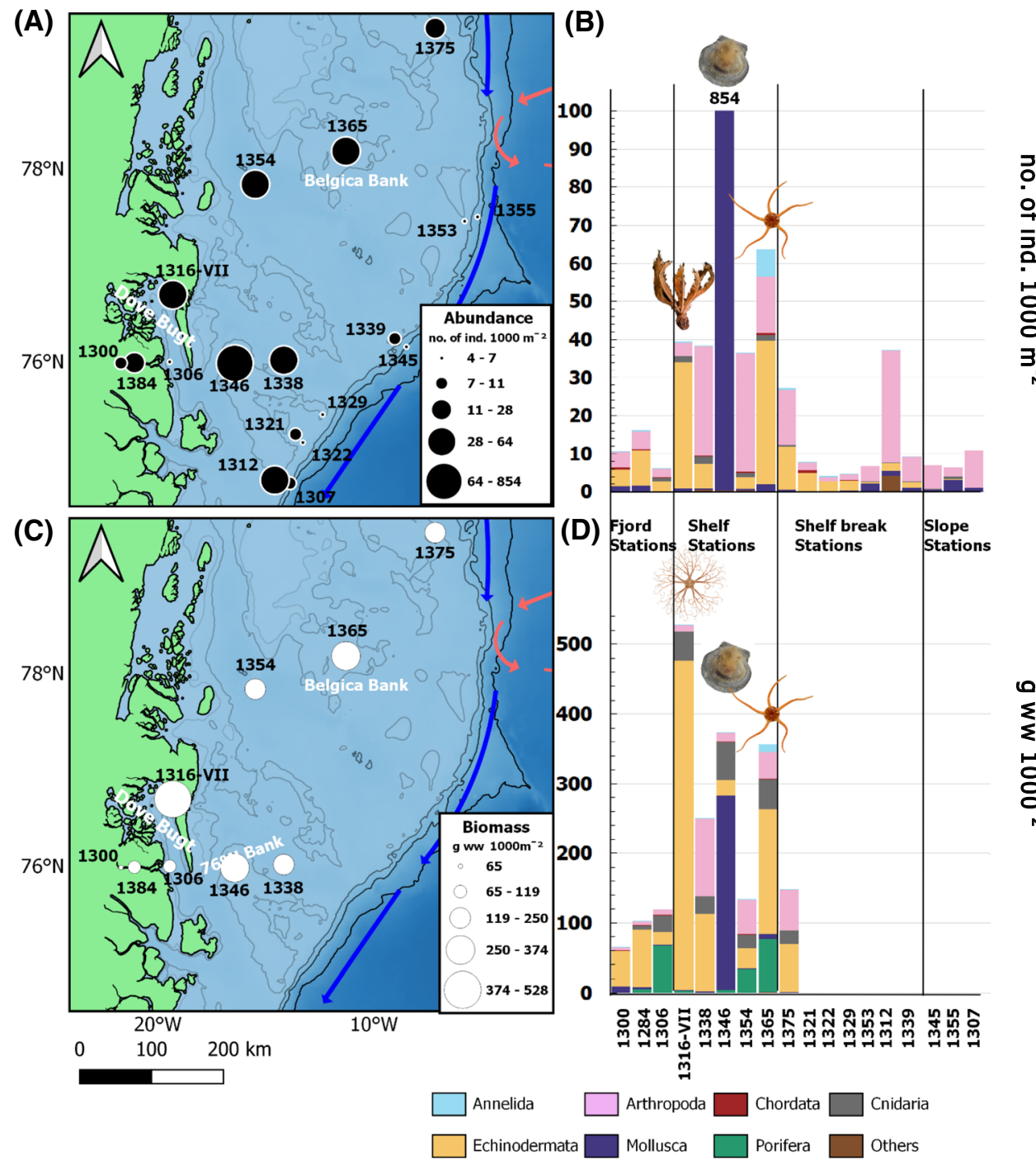

communities among habitats varied from $69 \%$ (fjord and shelf) to $88 \%$ (fjord and slope) (Online Resource 2).

\section{Environmental variables driving epibenthic communities}

The Principal Components (PC) 1 and 2 explained a combined variability of $74 \%$ of the variation in the environmental conditions across stations (Table 5, Fig. 6; sediment grain size excluded). PC axis 1 explained $55 \%$ of the variation with high $(>0.4)$ correlation coefficients for oxygen concentration, bottom salinity and temperature, and turbidity (Table 5, Fig. 6). Along the PC axis 1, two Bessel Fjord stations and the highly turbid $76^{\circ} \mathrm{N}$-Bank were separated from all the other stations. PC axis 2 explained 19\% of the variation with the highest correlation coefficients for depth and bottom temperature. Along this axis, the deeper and colder (Table 1) slope stations were separated from all the remaining shelf and shelf break stations. The single variable with the highest correlation coefficient for both BIO-ENV analyses was depth. The addition of oxygen and salinity slightly increased the correlation with the biological matrix (Table 6). Additional variables did not increase the correlation coefficient.

\section{Discussion}

\section{Variability of epibenthic community structure}

The inventory for the Northeast Greenland epibenthic invertebrates from both expeditions totaled 276 taxa at 18 locations with most taxa identified to species being widely distributed throughout the Arctic (Sirenko 2001). Clearly, the taxon accumulation curves (Fig. 3) show that further sampling is warranted to approach the true number of epibenthic taxa for Northeast Greenland. The number of taxa that was found in this study is not too far off from 


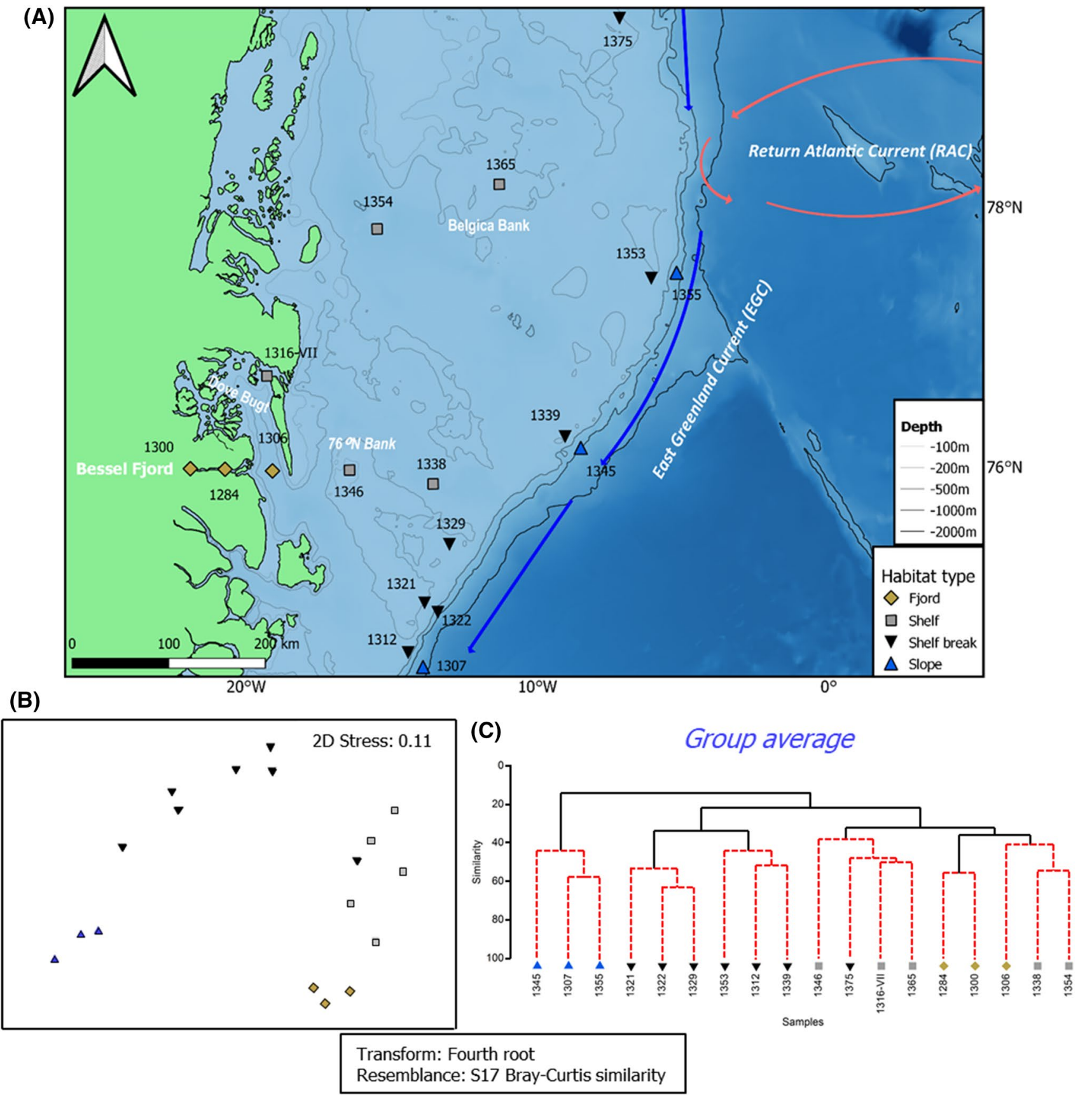

Fig. 5 Epifaunal community similarities of epibenthos from Northeast Greenland from Campelen trawl samples collected during TUNU-VI and TUNU-VII. a nMDS plot based on fourth-root transformed taxon abundance data, b Spatial distribution of habitat type

the 223 taxa Piepenburg (1988) identified from 17 Agassiz trawl catches just north of our study area, but is less than a tenth of the 3900-4700 macro- and megabenthic taxa Piepenburg et al. (2011) estimated to inhabit all Arctic shelves combined. While many of our taxa were found earlier in Northeast Greenland (Piepenburg 1988; Starmans communities. Stations are color-coded by habitat. c Station cluster with hierarchical cluster analysis, group average. Dotted line indicates clusters that are not statistically significant different (based by SIMPROF)

et al. 1999; Mayer and Piepenburg 1996; Piepenburg et al. 1997a, 1997b) this study still expanded the benthic inventory for this high Arctic region.

The most taxon-rich phylum in this study was Arthropoda. This is in agreement with a Eurasian Arctic-wide inventory (Sirenko 2001) and one in the Northeast Water (NEW) 
Table 3 Differences between epifaunal communities in a priori determined habitats

\begin{tabular}{|c|c|c|c|c|c|c|}
\hline Global test & Groups (habitat type) & $R$ statistics & Significance level & $\begin{array}{l}\text { Possible per- } \\
\text { mutations }\end{array}$ & $\begin{array}{l}\text { Actual per- } \\
\text { mutations }\end{array}$ & $\begin{array}{l}\text { Num- } \\
\text { ber } \geq \text { to } \\
R\end{array}$ \\
\hline Sample statistic $(R): 0.78$ & Slope, Shelf break & 0.75 & 0.008 & 120 & 120 & 1 \\
\hline Significance level of sample statistic: 0.001 & Slope, fjord & 1 & 0.1 & 10 & 10 & 1 \\
\hline $\begin{array}{l}\text { Number of permutations } \\
999 \text { (Random sample from } 147,026,880 \text { ) }\end{array}$ & Slope, Shelf & 1 & 0.018 & 56 & 56 & 1 \\
\hline \multirow{3}{*}{$\begin{array}{l}\text { Number of permuted statistics greater than } \\
\text { or equal to } R: 0\end{array}$} & Shelf break, Fjord & 0.85 & 0.008 & 120 & 120 & 1 \\
\hline & Shelf break, Shelf & 0.65 & 0.004 & 792 & 792 & 1 \\
\hline & Fjord, Shelf & 0.71 & 0.018 & 56 & 56 & 1 \\
\hline
\end{tabular}

Left: overall test, right: pairwise tests, all computed with one-way ANOSIM from a Bray-Curtis resemblance matrix on epifaunal abundance data from the TUNU expeditions to Northeast Greenland in 2015 and 2017. Strong community separation is indicated by an $R$ value close or equal to 1

Table 4 Epifaunal taxa caught in Campelen trawl hauls in Northeast Greenland that contribute to approximately $50 \%$ of the similarity within the four community groups that were used to detect a pattern in nMDS and hierarchical clustering. SD is standard deviation

\begin{tabular}{|c|c|c|c|c|c|}
\hline & $\begin{array}{l}\text { Av. Abun. } \\
\text { (ind. } \\
1000 \mathrm{~m}^{-2} \text { ) }\end{array}$ & $\begin{array}{l}\text { Av. simi- } \\
\text { larity (\%) }\end{array}$ & SD of similarity & $\begin{array}{l}\text { Contribu- } \\
\text { tion }(\%)\end{array}$ & Cumulative $(\%)$ \\
\hline \multicolumn{6}{|c|}{ Group Fjord (average similarity: 45\%) } \\
\hline Ophiopleura borealis & 1.3 & 7.4 & 5.3 & 16.2 & 16.2 \\
\hline Lebbeus polaris & 1.0 & 5.7 & 6.9 & 12.6 & 28.8 \\
\hline Themisto libellula & 1.0 & 5.6 & 16.4 & 12.3 & 41.1 \\
\hline Styela sp. & 0.7 & 4.1 & 35.6 & 9.0 & 50.1 \\
\hline \multicolumn{6}{|c|}{ Group shelf (average similarity: $40 \%$ ) } \\
\hline Lebbeus polaris & 1.3 & 3.4 & 2.8 & 8.5 & 8.5 \\
\hline Ophiopleura borealis & 1.4 & 3.4 & 4.0 & 8.4 & 16.8 \\
\hline Sabinea septemcarinata & 1.2 & 3.2 & 5.3 & 7.9 & 24.7 \\
\hline Umbellula encrinus & 1.0 & 2.7 & 6.4 & 6.8 & 31.5 \\
\hline Boreonymphon sp. & 0.8 & 2.4 & 6.0 & 6.0 & 37.5 \\
\hline Anonyx sp. & 0.9 & 1.9 & 1.1 & 4.7 & 42.2 \\
\hline Zoantharia & 0.7 & 1.6 & 1.2 & 4.1 & 46.3 \\
\hline Nymphon hirtipes & 0.8 & 1.6 & 1.2 & 3.9 & 50.1 \\
\hline \multicolumn{6}{|c|}{ Group shelf break (average similarity: 37\%) } \\
\hline Sclerocrangon ferox & 1.0 & 6.2 & 4.7 & 16.8 & 16.8 \\
\hline Lebbeus polaris & 1.1 & 5.5 & 2.3 & 14.9 & 31.7 \\
\hline Strongylocentrotus pallidus & 0.7 & 4.1 & 1.4 & 11.1 & 42.8 \\
\hline Ophiopleura borealis & 0.6 & 2.3 & 0.9 & 6.3 & 49.2 \\
\hline Crinoidea & 0.6 & 2.2 & 0.9 & 5.8 & 55.0 \\
\hline \multicolumn{6}{|c|}{ Group slope (average similarity: 49\%) } \\
\hline Gonatus sp. & 1.0 & 13.3 & 4.1 & 27.3 & 27.3 \\
\hline Pasiphaea tarda & 1.1 & 13.0 & 8.6 & 26.7 & 54.0 \\
\hline
\end{tabular}

polynya just north of our study area, where around 200 Peracarida species alone-many more than in the present study - were recorded using an epibenthic sledge, a gear type particularly well suited to catch Peracarida (Brandt 1997; Brandt and Berge 2007). Porifera was the second most taxa-rich phylum in the present study, and the most taxon-rich phylum in an inventory based on seabed images from the NEW polynya and close to Belgica Bank (Starmans et al. 1999). Though Porifera are difficult to identify to species level, 54 species were already recorded from Northeast Greenland in the early 1900s (Burton 1934) and a more recent study described 28 species of just calcareous Porifera (Calcarea) from Northeast Greenland, whereof six were new to Greenland (Rapp 2015). Regardless of the 
Table 5 Results of a Principal Component Analysis (PCA) of the six normalized environmental variables measured across both sampling years, showing the two first principal components that explain $74 \%$ of the variation in the environmental variables

\begin{tabular}{lll}
\hline & PC1 & PC2 \\
\hline Eigenvalues & 3.3 & 1.2 \\
\% Variation & 55 & 19 \\
Cum. \% variation & 55 & 74 \\
Eigenvectors & Correlation coef- & Correla- \\
& ficient & tion coef- \\
& & ficient \\
Latitude & 0.03 & -0.24 \\
Depth & $\mathbf{- 0 . 2 3}$ & $\mathbf{0 . 7 8}$ \\
Bottom oxygen & $\mathbf{0 . 5 2}$ & -0.11 \\
Bottom temperature & $\mathbf{- 0 . 4 1}$ & $\mathbf{- 0 . 5 5}$ \\
Bottom salinity (PSU) & $\mathbf{- 0 . 5 4}$ & -0.10 \\
Turbidity & $\mathbf{0 . 4 7}$ & -0.08 \\
\hline
\end{tabular}

Correlation coefficients $> \pm 0.4$ are in bold print

actual species number, repeated records of large poriferan communities along the Northeast Greenland shelf break and slope, and generally around the Northeast Atlantic (Mayer and Piepenburg 1996; Klitgaard and Tendal 2004; this study) suggest that Porifera are abundant and may play an ecologically important role. High density areas of Porifera are known to create habitat and shelter for many other species, thereby increasing spatial complexity and local biodiversity. This finding is true for both Arctic (Barthel and Brandt 1995) as well as Antarctic (Janussen and Downey 2014) shelf and slope areas and beyond, and contributes to the fact that sponge habitats receive special attention and active protection globally (Maldonado et al. 2017).

Abundance and biomass estimates of epibenthos in the present study appear to be low. The first reason is a gear bias rendering comparisons with Arctic shelf studies conducted with smaller-mesh trawls (e.g., Ravelo et al. 2015, 2020), or photographs (e.g., Starmans et al. 1999) invalid. A limitation of the present study is the large mesh size of the Campelen trawl used, resulting in small-bodied taxa or small individuals being missed, as found in other Arctic epibenthos studies that use invertebrate bycatch of fish-trawl surveys as a basis for benthic estimates (Logerwell et al. 2011; Jørgensen et al. 2015). In addition, however, low epibenthic standing stock estimates may also in part be related to low annual primary production in large parts of the study area (outside the NEW polynya) compared to Arctic inflow shelves (Wassmann et al. 2010; Grebmeier et al. 2015; Michel et al. 2015 and references therein). This in turn is caused by the steady advection of sea ice (affecting light climate), cold Arctic water in much of the euphotic zone (affecting algal growth rates), and low nitrate concentrations in water outflowing from the Eurasian Basin in the EGC (Codispoti et al. 2013; yet higher nitrate concentrations in the Atlantic water). These conditions may limit food availability in the fjords and on the Northeast Greenland Shelf section where the present study was conducted. Such conditions are in contrast to those at Arctic inflow shelves where the ice-covered period is shorter and advective supply of nutrients essentially
Fig. 6 Ordination of Principal Component Analysis (PCA) of six environmental variables (depth, latitude, bottom salinity, bottom temperature, bottom oxygen and turbidity) that were collected during TUNU-VI (2015) and TUNU-VII (2017) cruises. The vectors depicted in the graph are representing the direction and the strength of the environmental variables at each station based on Campelen 1800 Shrimp trawls

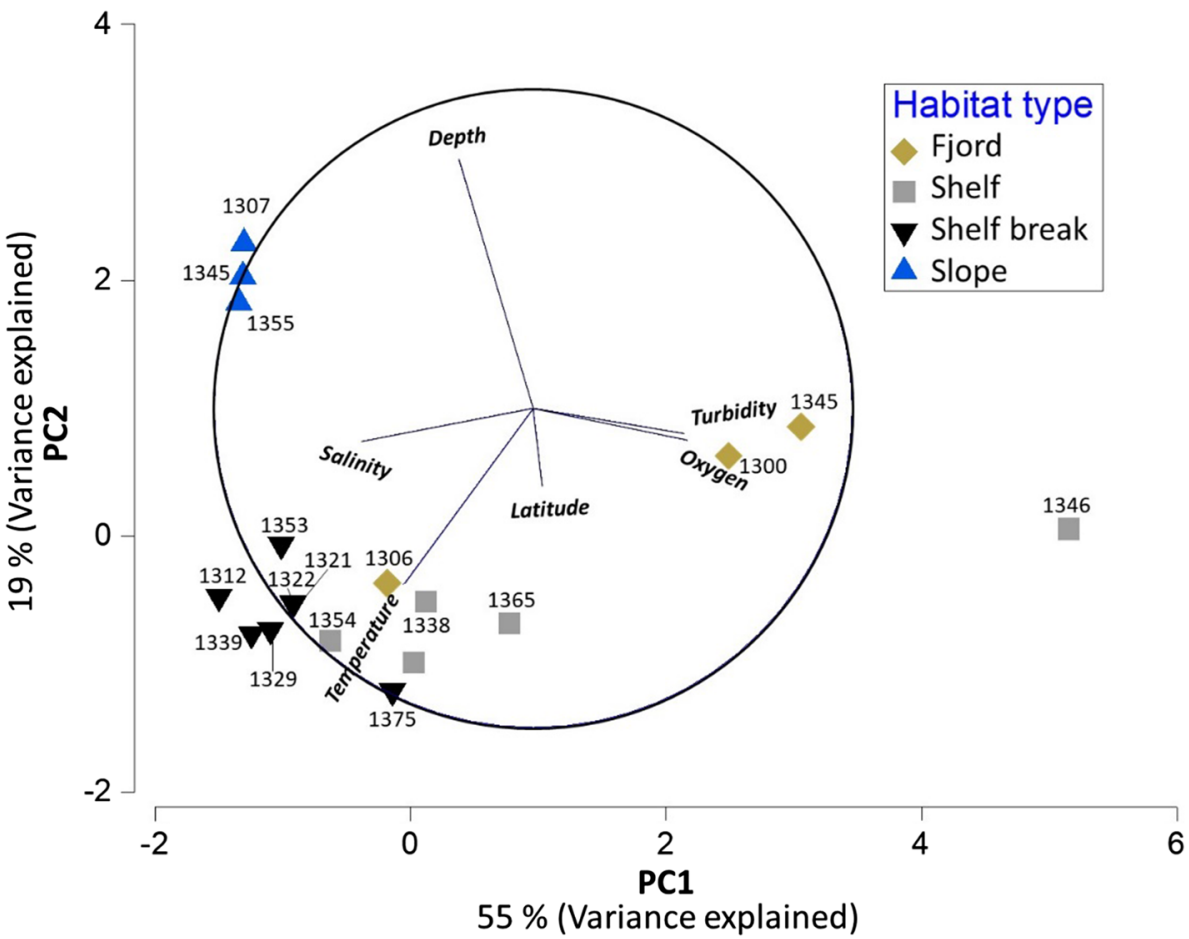


Table 6 Correlations of epifaunal community with environmental data matrices (BIO-ENV analysis)

\begin{tabular}{llc}
\hline $\begin{array}{l}\text { No. of environmental variables } \\
\text { Environmental variables from TUNU-VI }\end{array}$ & $\begin{array}{l}\text { ENV. variables with best combination to epiben- } \\
\text { thic community }\end{array}$ & $\begin{array}{l}\text { Correlation } \\
\text { coefficient }\end{array}$ \\
1 & Depth $T U N U$-VII (2017) & 0.58 \\
2 & Depth, bottom oxygen & 0.67 \\
3 & Depth, bottom oxygen, Turbidity & 0.64 \\
With additional environmental variables from TUNU-VII (2017) & \\
1 & Depth & 0.38 \\
2 & Depth, bottom salinity & 0.53 \\
3 & Depth, bottom oxygen, bottom salinity & 0.52 \\
\hline
\end{tabular}

First run includes the six environmental variables depth, latitude, bottom temperature, bottom salinity, turbidity, and bottom oxygen concentration available for both sampling years; second run also includes percentage sand and percentage mud but is for 2017 only. Table shows only the three most variables that correlated with the biological matrix continuous (Wassmann et al. 2010; Grebmeier et al. 2015), and to those in ice-covered waters of the Antarctic where, again, ice cover is less persistent and light climate boreal in comparison often allowing high megabenthic densities and biomass (Gutt and Starmans 1998).

The high relative contribution of Echinodermata-especially ophiuroids - to abundance and biomass throughout the study area is in agreement with earlier studies from other Arctic shelves (Starmans et al. 1999; Bluhm et al. 2009; Roy et al. 2014; Ravelo et al. 2015) and also from some Antarctic regions (Linse et al. 2013). Two proposed explanations for the success of echinoderms in the Arctic are, first, that their motility allows them to quickly respond to occasional food patches on the seabed, and, second, that large fish predators are less common in high Arctic compared to boreal seas (Nikolsky and Radakov 1968; Piepenburg 2000; Iken et al. 2001; Hamel et al. 2019). Other common echinoderms included the deposit-feeding holothuroid Molpadia borealis and asteroid Ctenodiscus crispatus (especially in Bessel Fjord) that are also common in other Arctic soft bottom areas where organic material accumulates, e.g. in parts of the Barents Sea (Jørgensen et al. 2015), the NEW polynya (Piepenburg et al. 1997b) and the Chukchi Sea (Bluhm et al. 2009). Arthropoda, in contrast, were particularly abundant on the shelf, at the shelf break and at some slope locations. This is in contrast to a previous study based on underwater imagery analysis along the Northeast Greenland shelf break (Mayer and Piepenburg 1996), perhaps because motile animals may escape from towed cameras (Lorance and Trenkel 2006). Within the phylum Mollusca, the very patchy occurrence of the pectinid bivalve Similipecten greenlandicus agrees with an earlier study that reported preference for and high densities at coarse bottom substrate (Ravelo et al. 2015).

\section{Environment and epibenthos}

Four distinct epibenthic communities were defined in the study area based on bathymetric and geomorphological features. Specifically, epibenthic communities shifted from a fjord environment (Bessel Fjord), across the shelf, towards the shelf break and at the slope.

\section{Bessel Fjord communities}

The Bessel Fjord has sills at the mouth, and the fjordic epibenthic community differed from the adjacent shelf locations. Within the fjord, however, epibenthic communities were relatively similar among the three sampling locations. The distinctive environmental conditions, particularly at the two innermost stations (Fig. 6), can be ascribed to high sedimentation rates and freshwater run-off from melting glaciers as well as ice scouring. While such potential disturbances may result in low taxon richness, abundance and biomass in Arctic fjords (Görlich et al. 1987; Holte and Gulliksen 1998; Sejr et al. 2000; Conlan and Kvitek 2005; Włodarska-Kowalczuk et al. 2005, 2012) Bessel Fjord in fact had higher taxon richness than the shelf break and slope locations, a pattern also found in fjords of the West Antarctic Peninsula (Grange and Smith 2013). Although high turbidity may smother and clog the organs of filter-feeding epibenthos (Hall 1994; Włodarska-Kowalczuk et al. 2005, 2012), the ascidian Styela spp. and some Porifera were found at the two innermost fjord stations indicating that the conditions were in fact suitable for this feeding mode. Overall, carbon sources were likely more diverse in the fjord than habitats further offshore given we found advected terrestrial plant material and macroalgal deposits at the seabed and these were shown to be suitable carbon sources after bacterial degradation in other Arctic fjords and shelves (Renaud et al. 2015; Bell et al. 2016) as well as Antarctic fjords (Grange and Smith 2013). 


\section{Shelf communities}

The shelf locations were distributed over a large geographic area with substantial habitat heterogeneity including deeper troughs and shallower banks with distinctive geomorphological features (Laberg et al. 2017). While the sample size was too limited to thoroughly characterize trough and bank communities separately in detail in this study, data from this and earlier studies suggest such benthic community differences do exist (Piepenburg and Schmid 1996; Starmans et al. 1999). In addition, hydrographic features along the Northeast Greenland shelf contribute to structuring epibenthic communities as shown in this and earlier studies (Piepenburg and Schmid 1996; Piepenburg et al. 1997a). Four out of five shelf stations were closely grouped based on similar depth and water mass properties (Fig. 6), in particular positive water temperatures originating from WSC (Schneider and Budéus 1997; Piepenburg and Schmid 1996a; Table 7). Water masses of Atlantic origin on the shelf explain the finding of the boreal deep water shrimp Pandalus borealis for which population genetic analyses revealed that the species is advected from the western Barents Sea (Spitsbergen) to the Northeast Greenland shelf (Andrews et al. 2019).

The shallow $76^{\circ} \mathrm{N}$-Bank $(65 \mathrm{~m})$ was environmentally distinct with high bottom oxygen content, subzero temperatures and comparatively low salinity as well as high turbidity
(Tables 1,7$)$. While the epibenthic community was largely similar to those of the other shelf stations, the presence of the amphipod Gammarus wilkitzkii is noteworthy as an indicator of cryo-benthic coupling. While this amphipod is typically associated with sea ice it may detach and survive for extended periods at the seabed once the sea ice melts (Aarset and Aunaas 1987; Werner et al. 1999). Recent melt of sea ice at the $76^{\circ} \mathrm{N}$-Bank was also supported by the low salinity and subzero temperatures. The total abundance and biomass at this shallow bank were much higher than at any other station because of a mass occurrence of the filter-feeding bivalve Similipecten greenlandicus. In an earlier study Piepenburg and Schmid (1996) suggested that organic carbon at Northeast Greenland banks might originate from polynyas further north highlighting the importance of polynyas to the surrounding environments. Perhaps organic material advected from the nearby NEW polynya combined with suitable substrate composition provides favorable conditions for Similipecten greenlandicus at the $76^{\circ} \mathrm{N}-\mathrm{Bank}$. This combination of factors may also explain high epifaunal abundance and biomass at Belgica Bank, which also had the highest taxon richness of all locations, perhaps related to the heterogeneous seabed habitat known to enhance biodiversity compared to more uniform soft substrates (Buhl-Mortensen et al. 2012). Abundance and biomass were higher on the shelf than at slope stations, likely because vertical carbon

Table 7 Summary table of the different habitats with description, the species most contributing to the similarity within habitat type, depth range, temperature and salinity range and bottom oxygen from Campelen trawls from both years (2015 and 2017) in the TUNU-program

\begin{tabular}{|c|c|c|c|c|c|c|}
\hline $\begin{array}{l}\text { Habitat, com- } \\
\text { munity, similarity } \\
\text { level }\end{array}$ & $\begin{array}{l}\text { Description of habitat } \\
\text { type }\end{array}$ & Contributing species & Prevalent water types & $\begin{array}{l}\text { Depth range } \\
\text { sampled }(\mathrm{m})\end{array}$ & $T-S$ range $\left({ }^{\circ} \mathrm{C}\right)$ & $\begin{array}{l}\text { Bottom } \\
\text { oxygen }(\mathrm{ml} \\
\left.\mathrm{L}^{-1}\right)\end{array}$ \\
\hline Fjord $45 \%$ & $\begin{array}{l}\text { Submerged gla- } \\
\text { cially—carved } \\
\text { valleys, silled }\end{array}$ & $\begin{array}{l}\text { Ophiopleura } \\
\text { borealis, Lebbeus } \\
\text { polaris, Themisto } \\
\text { libellula, Styela } \\
\text { spp. }\end{array}$ & Glacial melt water & $237-484$ & $\begin{array}{l}-1.5 \text { to } 1.6 \\
33.4 \text { to } 34.9\end{array}$ & $6.0-6.8$ \\
\hline Shelf $40 \%$ & $\begin{array}{l}\text { Area offshore of } \\
\text { coast to shelf break, } \\
\text { low slope }\end{array}$ & $\begin{array}{l}\text { L. polaris, } O \text {. } \\
\text { borealis, Sabinea } \\
\text { septemcarinata, } \\
\text { Umbellula encri- } \\
\text { nus, Boreonymphon } \\
\text { sp., Anonyx sp., } \\
\text { Zoantharia, Nym- } \\
\text { phon hirtipes }\end{array}$ & $\begin{array}{l}\text { East Greenland Cur- } \\
\text { rent (EGC) }\end{array}$ & $65-440$ & $\begin{array}{l}1.1 \text { to } 1.5 \\
34.7-34.9 \\
\text { (shallow bank: } \\
-1.6,32.5 \text { ) }\end{array}$ & $6.4-7.9$ \\
\hline Shelf break $37 \%$ & $\begin{array}{l}\text { Edge of shelf where } \\
\text { slope becomes } \\
\text { steeper }\end{array}$ & $\begin{array}{l}\text { Sclerocrangong } \\
\text { ferox, L. polaris, } \\
\text { Strongylocentro- } \\
\text { tus pallidus, } O . \\
\text { borealis }\end{array}$ & $\begin{array}{l}\text { Return Atlantic Cur- } \\
\text { rent, EGC }\end{array}$ & $177-385$ & $\begin{array}{l}0.1 \text { to } 1.8 \\
34.8-35.0\end{array}$ & $5.6-5.8$ \\
\hline Upper slope $49 \%$ & $\begin{array}{l}\text { Steeply sloping part } \\
\text { of margin under } \\
\text { shelf break and } \\
\text { above rise }\end{array}$ & $\begin{array}{l}\text { Gonatus sp., } \\
\text { Pasiphaea tarda }\end{array}$ & $\begin{array}{l}\text { Slope current, inter- } \\
\text { mediate and deep } \\
\text { water }\end{array}$ & $937-1011$ & $\begin{array}{l}-0.11 \text { to }-0.17 \\
34.9\end{array}$ & 5.7 \\
\hline
\end{tabular}

$S$ salinity, $T$ temperature 
flux, i.e. food supply, tends to strongly decline with increasing depth (Wei et al. 2010).

\section{Shelf break communities}

The shelf break community displayed the lowest within habitat similarity, perhaps related to the pronounced habitat heterogeneity along the regional shelf break documented in imagery by Mayer and Piepenburg (1996). Geophysical records show evidence that the Greenland Ice Sheet reached the continental shelf break in Northeast Greenland during the last glacial maximum (26 500-20 000 years BP, Clark et al. 2009) leaving glacial traces on the seafloor (Laberg et al. 2017). The subsequent deglaciation left ice-rafted drop stones on the seabed (Schulz et al. 2010; Ziegler et al. 2017) which create small-scale heterogeneity facilitating biological patchiness. In fact, drop stones have even been observed at depths $>1000 \mathrm{~m}$ in the Fram Strait and the Canada Basin (MacDonald et al. 2010; Taylor et al. 2016; Zhulay et al. 2019). In those studies and at various shelf breaks the increased heterogeneity also increased taxon richness on a local scale (Mayer and Piepenburg 1996; Buhl-Mortensen et al. 2012; Ravelo et al. 2015, 2020), but the shelf break stations in the present study in fact exhibited the lowest taxon richness. The cause is unclear, though poorer performance of our trawl on the uneven seabed topography might be a contributing factor.

Hydrographically, the shelf break community encounters two primary currents, first, the deflecting Return Atlantic Current (RAC) that converges with the EGC at the shelf break (Bourke et al. 1987; Christiansen et al. 2016). Again, the Atlantic connection on the Northeast Greenland shelf and along the shelf break is reflected in the occurrence of the boreal deep water shrimp Pandalus borealis. Second, the southbound EGC which may reach velocities exceeding $10 \mathrm{~cm} \mathrm{~s}^{-1}$ near the seafloor at the shelf break (Håvik et al. 2017) may both create coarser sediments suitable for sessile biota and probably provide a sustained - even if at low concentrations - supply of food for the documented filter feeders (this study, Mayer and Piepenburg 1996). Indirect evidence of coarser sediments, regardless of the source, is given by the presence of characteristic hard-bottom epibenthos such as echinoderms Strongylocentrotus pallidus and Crinoidea, and by the fact that box coring failed due to a lack of soft sediments.

\section{Slope communities}

At continental slopes, epibenthic community changes are particularly evident because depth increases quickly over short geographic distances (Mayer and Piepenburg 1996; Buhl-Mortensen et al. 2012). This strong community shift with depth was reflected in the high dissimilarity of slope and shelf communities also found at other slopes (BuhlMortensen et al. 2012; Ravelo et al. 2020). Such a shift was for example seen in the abrupt appearance of the deep-dwelling glass shrimp Pasiphaea tarda beyond the shelf break. Also, the ophiuroid Ophiopleura borealis was absent from the slope but abundant on the shelf in the present study, though this distribution pattern appears to contradict Piepenburg et al. (1997b) and Ravelo et al. $(2015,2020)$ who found that $O$. borealis was absent from the shelf but present on the slope near our study area and in the Beaufort Sea, respectively.

While the three slope locations were geographically far apart, their communities were rather similar, with relatively similar depth and hydrography (Table 7), a finding similar to slope communities along the Arctic interior Beaufort Sea (Ravelo et al. 2020). Abundances were also similarly low at these slope locations, consistent with the decreasing amount of food particles that reach the seabed with increasing depth (Riser et al. 2008) in the study area. This situation matches the character of the area as an outflow shelf and slope, while upper slopes in Arctic inflow areas benefit from particle loads advected from sub-Arctic seas (Bluhm et al. in review).

\section{Conclusions and outlook}

This work presents a contemporary baseline for epibenthic communities in Northeast Greenland including fjord, shelf, shelf break and slope habitats. Thereby an inshoreto-upper slope gradient has been added to earlier studies that either focused on areas further north (Piepenburg and Schmid 1996), the shelf break and slope transition (Mayer and Piepenburg 1996), bank and trough structure (Starmans et al. 1999), the NEW polynya (Piepenburg et al. 1997a), fjord benthos (Sejr et al. 2000) or a particular taxon (Brandt and Berge 1997, Piepenburg et al. 1997b). It is shown in this study that epibenthic communities vary along this gradient, with a combination of depth and hydrography explaining part of the variation in community structure. As seen in other ocean areas, deep water stations contain some specific taxa not occurring elsewhere; certain shelf taxa are missing from fjords; many other taxa occur widely, yet in different proportions in different habitats, while a few others are highly patchy (Table 7). Indicator species give evidence of system connectivity such as the boreal deep water shrimp Pandalus borealis that strengthens the idea that organisms may advect all the way from the Barents Sea via the Fram Strait to the Northeast Greenland shelf (Andrews et al. 2019), and the usually sympagic amphipod Gammarus wilkitzkii whose occurrence at the seafloor may indicate successful avoidance of exiting the Arctic through sea ice export. In light of 
climate change, it is hence even more important to monitor where Arctic and sub-Arctic biota meet in a warmer Arctic Ocean, and to interpret species' biology in light of system processes. Future studies of epibenthic communities should also combine seabed mapping with epifauna functional characterization to arrive at more detailed habitat mapping and support species distribution models.

Acknowledgements This study forms part of the TUNU Programme at UiT-The Arctic University of Norway and is the first contribution focused on benthic invertebrates in this Programme. The TUNU-Programme received permits from the Government of Greenland, Ministry of Fisheries, Hunting and Agriculture-document ID: C-17-129 and C-15-17. We thank the crew of RV Helmer Hanssen and the TUNUVI \& VII field teams for their valuable support onboard. We gratefully acknowledge taxonomic support by J. Berge (UiT-The Arctic University of Norway, Amphipoda), O. Tendal (University of Copenhagen Zoological Museum, Porifera), and C. Mah (Smithsonian Institution, Asteroidea). Sediment grain size samples were collected by collaborating geologists in the Programme.

Author contributions JSC, EB, MN and BB conceived and designed the research. RF, EB, LHL, MN and IZ collected the samples. RF analyzed the data, advised by BB and JSC. RF wrote the manuscript, RF and $\mathrm{BB}$ revised the manuscript, and all authors contributed to writing and discussion, and approved the manuscript.

Funding Open Access funding provided by UiT The Arctic University of Norway. RF, JSC, IZ and BAB received support from UiT, and EB and MN from The Åbo Akademi University Foundation.

\section{Compliance with ethical standards}

Conflict of interest The authors declear that they have no conflict of interest.

Open Access This article is licensed under a Creative Commons Attribution 4.0 International License, which permits use, sharing, adaptation, distribution and reproduction in any medium or format, as long as you give appropriate credit to the original author(s) and the source, provide a link to the Creative Commons licence, and indicate if changes were made. The images or other third party material in this article are included in the article's Creative Commons licence, unless indicated otherwise in a credit line to the material. If material is not included in the article's Creative Commons licence and your intended use is not permitted by statutory regulation or exceeds the permitted use, you will need to obtain permission directly from the copyright holder. To view a copy of this licence, visit http://creativecommons.org/licenses/by/4.0/.

\section{References}

Aarset AV, Aunaas T (1987) Osmotic responses to hyposmotic stress in the amphipods Gammarus wilkitzkii, Onisimus glacialis and Parathemisto libellula from Arctic waters. Polar Biol 7:189-193. https://doi.org/10.1007/BF00287415

Aastrup P, Boertmann, D (2009) Biologiske beskyttelsesområder i nationalparkområdet, Nord-og Østgrønland Danmarks Miljøundersøgelser, Aarhus Universitet
Andrews AJ, Christiansen JS, Bhat S, Lynghammar A, Westgaard JI, Pampoulie C, Praebel K (2019) Boreal marine fauna from the Barents Sea disperse to Arctic Northeast Greenland. Sci Rep UK 9:5799. https://doi.org/10.1038/s41598-019-42097-x

Ambrose WG, Renaud PE (1995) Benthic response to water column productivity patterns: evidence for benthic-pelagic coupling in the Northeast Water Polynya. J Geophys Res Oceans 100(C3):4411-4421. https://doi.org/10.1029/94JC01982

Ambrose WG, Clough L, Tilney P, Beer L (2001) Role of echinoderms in benthic remineralization in the Chukchi Sea. Mar Biol 139:937-949. https://doi.org/10.1007/s002270100652

Arndt JE, Jokat W, Dorschel B, Myklebust R, Dowdeswell JA, Evans J (2015) A new bathymetry of the Northeast Greenland continental shelf: constraints on glacial and other processes. Geochem Geophys Geosyst 16(10):3733-3753. https://doi.org/10.1594/ PANGAEA.849313

Ashley GM, Smith ND (2000) Marine sedimentation at a calving glacier margin. Geol Soc Am Bull 112:657-667. https://doi. org/10.1130/0016-7606(2000)112<657:MSAACG >2.0.CO;2

Barr L (1970) Diel vertical migration of Pandalus borealis in Kachemak Bay, Alaska. J Fish Bd Can 27:669-676. https://doi. org/10.1139/f70-071

Barthel D, Brandt A (1995) Caecognathia robusta (GO Sars, 1879) (Crustacea, Isopoda) in Geodia mesotriaena (Hentschel, 1929) (Demospongiae, Choristidae) at $75 \mathrm{~N}$ off NE Greenland. Sarsia 80:223-228. https://doi.org/10.1080/00364827.1995.10413594

Bell LE, Bluhm BA, Iken K (2016) Influence of terrestrial organic matter in marine food webs of the Beaufort Sea shelf and slope. Mar Ecol Prog Ser 550:1-24. https://doi.org/10.3354/meps11725

Bjørke H, Gjøsæter H (1998) Who eats the larger Gonatus fabricii (Lichtenstein) in the Norwegian Sea? ICES C.M Pap M:10.

Bluhm BA, Gradinger R (2008) Reginal variability in food availability for Arctic marine mammals. Ecol Appl 18:77-96. https://doi. org/10.1890/06-0562.1

Bluhm BA, Iken K, Hardy SM, Sirenko BI, Holladay BA (2009) Community structure of epibenthic megafauna in the Chukchi Sea. Aquat Biol 7:269-293. https://doi.org/10.3354/ab00198

Bluhm BA, Kosobokova KN, Carmack EC (2015) A tale of two basins: an integrated physical and biological perspective of the deep Arctic Ocean. Progr Oceanogr 139:89-121. https://doi.org/10.1016/j. pocean.2015.07.011

Bluhm BA, Janout M, Danielson S, Elligsen I, Gavrile M, Grebmeier $\mathrm{JM}$ et al. The pan-Arctic continental slope: a narrow band of sharp physical gradients affecting pelagic and benthic ecosystems. Frontiers Mar Sci, accepted with minor revision

Bourke RH, Newton JL, Paquette RG, Tunnicliffe MD (1987) Circulation and water masses of the East Greenland Shelf. J Geophys Res 92(C7):6729-6740. https://doi.org/10.1029/JC092iC07p 06729

Brandt A (1997) Abundance, diversity and community patterns of epibenthic-and benthic boundary layer peracarid crustaceans at $75 \mathrm{~N}$ off East Greenland. Polar Biol 17:159-174. https://doi. org/10.1007/s003000050118

Brandt A, Berge J (2007) Peracarid composition, diversity and species richness in the area of the Northeast Water polynya, East Greenland (Crustacea, Malacostraca). Polar Biol 31:15-22. https://doi. org/10.1007/s00300-007-0327-6

Bray JR, Curtis JT (1957) An ordination of the upland forest communities of Southern Wisconsin. Ecol Monogr 27:325-349. https:// doi.org/10.2307/1942268

Brey T (2001) Population dynamics in benthic invertebrates. A virtual handbook. Version 01.2

Brey T, Müller-Wiegmann C, Zittier ZM, Hagen W (2010) Body composition in aquatic organisms: a global data bank of relationships between mass, elemental composition and energy content. J Sea Res 64:334-340. https://doi.org/10.1016/j.seares.2010.05.002 
Buhl-Mortensen L, Buhl-Mortensen P, Dolan MFJ, Dannheim J, Bellec V, Holte B (2012) Habitat complexity and bottom fauna composition at different scales on the continental shelf and slope of northern Norway. Hydrobiol 685:191-219. https://doi.org/10.1007/ s10750-011-0988-6

Burton M (1934) Zoological results of the Norwegian Scientific Expedition to East Greenland III. Report on the sponges of the Norwegian Expeditions to East Greenland (1930, 1931 and 1932). Skrift Svalb Ishavet 61:3-34

Buzhinskaja GN (2010) Illustrated keys to free-living invertebrates of Eurasian Arctic seas and adjacent deep waters. Nemertea, Cephalorincha, Oligochaeta, Hirudinea, Pogonophora, Echiura, Sipuncula, Phoronida and Brachiopoda, 2. Alaska Sea Grant, University of Alaska Fairbanks

Carmack E, Wassmann P (2006) Food webs and physical-biological coupling on pan-Arctic shelves: unifying concepts and comprehensive perspectives. Progr Oceanogr 90:90-104. https://doi. org/10.1016/j.pocean.2006.10.004

Christiansen JS (2012) The TUNU-Programme: Euro-Arctic marine fishes-diversity and adaptation. Adapt Evol Mar Environ $1: 35-50$

Christiansen JS, Bonsdorff E, Byrkjedal I, Fevolden SE, Karamushko OV, Lynghammar A, Mecklenburg CW, Møller PDR, Nielsen J, Nordström MC, Præbel K, Wienerroither RM (2016) Novel biodiversity baselines outpace models of fish distribution in Arctic waters. Sci Nat 103:1-8. https://doi.org/10.1007/s0011 4-016-1332-9

Christiansen JS (2017) No future for Euro-Arctic ocean fishes? Mar Ecol Prog Ser 575:217-227

Clarke KR, Warwick RM (2001) Change in marine communities: an approach to statistical analysis and interpretation, 2nd edn. PRIMER-E, Plymouth

Clarke KR, Gorley RN (2006) PRIMER v6: user manual/tutorial. PRIMER-E Ltd, Plymouth

Clark PU, Dyke AS, Shakun JD, Carlson AE, Clark J, Wohlfarth B, Mitrovica JX, Hostetler SW, McCabe AM (2009) The last glacial maximum. Science 325(5941):710-714. https://doi.org/10.1126/ science. 1172873

Codispoti LA, Kelly V, Thessen A, Matrai P, Suttles S, Hill V, Steele M, Light B (2013) Synthesis of primary production in the Arctic Ocean: III. Nitrate and phosphate based estimates of net community production. Progr Oceanogr 110:126-150. https://doi. org/10.1016/j.pocean.2012.11.006

Conlan KE, Kvitek RG (2005) Recolonization of soft-sediment ice scours on an exposed Arctic coast. Mar Ecol Prog Ser 286:21-42. https://doi.org/10.3354/meps286021

Eleftheriou A, McIntyre A (2005) Methods for the study of marine benthos. Blackwell, Oxford

Field JG, Clarke KR, Warwick RM (1982) A practical strategy for analyzing multispecies distribution pattern. Mar Ecol Prog Ser 8:37-52

Fossheim M, Primicerio R, Johannesen E, Ingvaldsen RB, Aschan MM, Dolgov AV (2015) Recent warming leads to a rapid borealization of fish communities in the Arctic. Nat Clim Change 5:673-677. https://doi.org/10.1038/nclimate2647

Funder S, Hjort C, Landvik JY, Nam S-I, Reeh N, Stein R (1998) History of a stable ice margin: East Greenland during the middle and upper Pleistocene. Quart Sci Rev 17:77-123. https://doi. org/10.1016/S0277-3791(97)00082-6

Godø OR, Engås A (1989) Swept area variation with depth and its influence on abundance indices of groundfish from trawl surveys. J NW Atl Fish Sci 9:133-139

Grange LJ, Smith CR (2013) Megafaunal communities in rapidly warming fjords along the West Antarctic Peninsula: hotspots of abundance and beta diversity. PLoS ONE 8:1-17
Grebmeier JM, Bluhm BA, Cooper LW, Danielson SL, Arrigo KR, Blanchard AL, Clarke JT, Day RH, Frey KE, Gradinger RR, Kędra M, Konar B, Kuletz KJ, Lee SH, Lovvorn JR, Norcross BL, Okkonen SR (2015) Ecosystem characteristics and processes facilitating persistent macrobenthic biomass hotspots and associated benthivory in the Pacific Arctic. Progr Oceanogr 136:92114. https://doi.org/10.1016/j.pocean.2015.05.006

Gutt J, Starmans A (1998) Structure and biodiversity of megabenthos in the Weddell and Lazarev Seas (Antarctica): ecological role of physical parameters and biological interactions. Polar Biol 20:229-247. https://doi.org/10.1007/s003000050300

Görlich K, Weslawski JM, Zajaczkowski M (1987) Suspension settling effect on macrobenthos biomass distribution in the Hornsund fjord, Spitsbergen. Polar Res 5:175-192. https://doi.org/10.3402/ polar.v5i2.6875

Hall SJ (1994) Physical disturbance and marine benthic communities: life in unconsolidated sediments. Oceanogr Mar Biol 32:179-239

Halpern BS, Frazier M, Potapenko J, Casey KS, Koenig K, Longo C, Lowndes JS, Rockwood RC, Selig ER, Selkoe KA, Walbridge $S$ (2015) Spatial and temporal changes in cumulative human impacts on the world's ocean. Nat Commun 6:1-7

Hamel JF, Sun J, Gianasi BL, Montgomery EM, Kenchington EL, Burel B, Rowe S, Winger PD, Mercier A (2019) Active buoyancy adjustment increases dispersal potential in benthic marine animals. J Anim Ecol 88:820-832. https://doi. org/10.1111/1365-2656.12943

Harris EK, Baker PT (2020) Chapter 2: Habitat mapping and marine management. In: Baker EK, Harris PT (eds) Seaflor geomorphology as benthic habitat. Elsevier, London, pp 17-33

Hay WW (2016) Continental slope. In: Harff J, Meschede M, Petersen $\mathrm{S}$, Thiede J (eds) Encyclopedia of marine geosciences. Springer, Berlin

Hirche HJ, Laudien J, Buchholz F (2016) Near-bottom zooplankton aggregations in Kongsfjorden: implications for pelago-benthic coupling. Polar Biol 39:1897-1912

Holte B, Gulliksen B (1998) Common macrofaunal dominant species in the sediments of some north Norwegian and Svalbard glacial fjords. Polar Biol 19:375-382. https://doi.org/10.1007/s0030 00050262

Hopkins TS (1991) The GIN Sea: a synthesis of its physical oceanography and literature review 1972-1985. Earth Sci Rev 30:175-318. https://doi.org/10.1016/0012-8252(91)90001-V

Hopkins CCE, Nilssen EM (1990) Population biology of the deepwater prawn (Pandalus borealis) in Balsfjord, northern Norway: I. Abundance, mortality, and growth, 1979-1983. ICES J Mar Sci 47:148-166. https://doi.org/10.1093/icesjms/47.2.148

Howe JA, Austin WEN, Forwick M, Paetzel M (eds) (2010) Fjord systems and archives: geological Society. Special Publication, London, p 344

Håvik L, Pickart RS, Våge K, Torres D, Thurnherr AM, BeszczynskaMöller A, Walczokski W, von Appen WJ (2017) Evolution of the East Greenland current from Fram Strait to Denmark Strait: synoptic measurements from summer 2012. J Geophys Res 122:1974-1994. https://doi.org/10.1002/2016JC012228

Iken K, Brey T, Wand U, Voigt J, Junghans P (2001) Food web structure of the benthic community at the Porcupine Abyssal Plain (NE Atlantic): a stable isotope analysis. Progr Oceanogr 50:383405. https://doi.org/10.1016/S0079-6611(01)00062-3

Jakobsson M (2002) Hypsometry and volume of the Arctic Ocean and its constituent seas. Geochem Geophy Geosyst 35:1-18

Jakobsson M, Mayer LA, Coakley B, Dowdeswell JA, Forbes S, Fridman B, Hodnesdal H, Noormets R, Pedersen R, Rebesco M, Schenke H-W, Zarayskaya Y, Accettella D, Armstrong A, Anderson RM, Bienhoff P, Camerlenghi A, Church I, Edwards M, Gardner JV, Hall JK, Hell B, Hestvik O, Kristoffersen Y, Marcussen C, Mohammad R, Mosher D, Nghiem SV, Pedrosa 
MT, Travaglini PG, Weatherall P (2012) The international bathymetric chart of the Arctic Ocean (IBCAO) version 3.0. Geophys Res Lett. https://doi.org/10.1029/2012GL052219

Janussen D, Downey RV (2014) Porifera. In: De Broyer C, Koubbi P, Griffiths H, Raymond B, d'Udekem, d'Acoz C, Van de Putte A (eds) Biogeographic atlas of the Southern Ocean. Cambridge. Scientific Committee on Antarctic Research, pp 94-102

Johnson C, Barmuta, L (2015) Quantitative methods: Notes on the design and analysis of biological experiments. University of Tasmania, Institute for Marine and Antarctic Studies

Jørgensen LL, Planque B, Thangstad TH, Certain G (2015) Vulnerability of megabenthic species to trawling in the Barents Sea. ICES J Mar Sci 73:84-97. https://doi.org/10.1093/icesjms/fsv107

Klitgaard AB, Tendal OS (2004) Distribution and species composition of mass occurrences of large-sized sponges in the northeast Atlantic. Progr Oceanogr 61:57-98. https://doi.org/10.1016/j. pocean.2004.06.002

Khan SA, Kjær KH, Bevis M, Bamber JL, Wahr J, Kjeldsen KK, Bjørk AA, Korsgaard NJ, Stearns LA, van den Broeke MR, Liu L, Larsen NK, Muresan IS (2014) Sustained mass loss of the northeast Greenland ice sheet triggered by regional warming. Nat Clim Change 4:292. https://doi.org/10.1038/nclimate2161

Kruskal JB, Wish M (1978) Multidimensional scaling. Sage, Beverly Hills

Laberg JS, Forwick M, Husum K (2017) New geophysical evidence for a revised maximum position of part of the NE sector of the Greenland ice sheet during the last glacial maximum. Arktos 3:1-9. https://doi.org/10.1007/s41063-017-0029-4

Lorance P, Trenkel VM (2006) Variability in natural behaviour, and observed reactions to an ROV, by mid-slope fish species. J Exp Mar Biol Ecol 332:106-119. https://doi.org/10.1016/j.jembe .2005.11.007

Last PR, Lyne VD, Williams A, Davies CR, Butler AJ, Yearsley GK (2010) A hierarchical framework for classifying seabed biodiversity with application to planning and managing Australia's marine biological resources. Biol Conserv 143:1675-2168

Linse K, Griffiths HJ, Barnes DK, Brandt A, Davey N, David B, De Grave S, Eléaume M, Glover AG, Hemery LG, Mah C (2013) The macro-and megabenthic fauna on the continental shelf of the eastern Amundsen Sea, Antarctica. Cont Shelf Res 68:80-90

Logerwell E, Rand K, Weingartner TJ (2011) Oceanographic characteristics of the habitat of benthic fish and invertebrates in the Beaufort Sea. Polar Biol 34:1783-1796. https://doi.org/10.1007/ s00300-011-1028-8

MacDonald IR, Bluhm BA, Iken K, Gagaev S, Strong S (2010) Benthic macrofauna and megafauna assemblages in the Arctic deep-sea Canada Basin. Deep Sea Res Part II 57:136-152. https://doi. org/10.1016/j.dsr2.2009.08.012

Maldonado M, Aguilar R, Bannister RJ, Bell JJ, Conway KW, Dayton PK, Díaz C, Gutt J, Kelly M, Kenchington SP, Leys SP, Pomponi SA, Rapp HT, Rützler K, Tental OS, Vacelet J, Young CM (2017) Sponge grounds as key marine habitats: a synthetic review of types, structure, functional roles, and conservation concerns. In: Rossi S (ed) Marine animal forests. Springer, Dodretch, pp 1-39

Mayer M, Piepenburg D (1996) Epibenthic community pattern on the continental slope off East Greenland at 75 N. Mar Ecol Prog Ser 143:151-164. https://doi.org/10.3354/meps143151

Michel C, Hamilton J, Hansen E, Barber E, Reigstad M, Iacozza J, Seuthe L, Niemi A (2015) Arctic Ocean outflow shelves in the changing Arctic: a review and perspectives. Progr Oceanogr 139:66-88. https://doi.org/10.1016/j.pocean.2015.08.007

Nikolsky GV, Radakov DV (1968) Food interrelations of pelagic fish in the northern seas. Rapp Proc Verb 158

Paquette RG, Bourke RH, Newton JF, Perdue WF (1985) The East Greenland polar front in autumn. J Geophys Res 90(C3):48664882. https://doi.org/10.1029/JC090iC03p04866
Piepenburg D (1988) On the composition of the benthic fauna of the western Fram Strait. Ber Polarforsch 52:118

Piepenburg D, Schmid MK (1996) Distribution, abundance, biomass, and mineralization potential of the epibenthic megafauna of the Northeast Greenland shelf. Mar Biol 125:321-332. https://doi. org/10.1007/BF00346313

Piepenburg D, Ambrose WG, Brandt A, Renaud PE, Ahrens MJ, Jensen P (1997) Benthic community pattern reflect water column processes in the Northeast Water Polynya (Greenland). J Mar Syst 10:467-482. https://doi.org/10.1016/S0924-7963(96)00050-4

Piepenburg D, Voß J, Gutt J (1997) Assemblages of sea stars (Echinodermata: Asteroidea) and brittle stars (Echinodermata: Ophiuroidea) in the Weddell Sea (Antarctica) and off Northeast Greenland (Arctic): a comparison of diversity and abundance. Polar Biol 17:305-322. https://doi.org/10.1007/PL00013372

Piepenburg D (2000) Arctic brittle stars (Echinodermata: Ophiuroidea). Oceanogr Mar Biol 38:189-256

Piepenburg D, Archambault P, Ambrose WG Jr, Blanchard AL, Bluhm BA, Carroll ML, Conlan KE, Cusson M, Feder HM, Grebmeier JM, Jewett SC, Lévesque M, Petryashew VV, Sejr MK, Sirenko BI, Wlodarska-Kowalczuk M (2011) Towards a pan-Arctic inventory of the species diversity of the macroand megabenthic fauna of the Arctic shelf seas. Mar Biodivers 41:51-70. https://doi.org/10.1007/s12526-010-0059-7

Rapp HT (2015) A monograph of the calcareous sponges (Porifera, Calcarea) of Greenland. J Mar Biol Assoc UK 95:1395-1459. https://doi.org/10.1017/S0025315413001070

Ravelo AM, Konar B, Bluhm BA (2015) Spatial variability of epibenthic communities on the Alaska Beaufort Shelf. Polar Biol 38:1783-1804. https://doi.org/10.1007/s00300-015-1741-9

Ravelo AM, Bluhm BA, Foster N, Iken B (2020) Biogeography of epibenthic assemblages in the central Beaufort Sea. Mar Biodivers 50:8

Renaud PE, Løkken TS, Jørgensen LL, Berge J, Johnson BJ (2015) Macroalgal detritus and food-web subsidies along an Arctic fjord depth-gradient. Front Mar Sci 2:31. https://doi. org/10.3389/fmars.2015.00031

Riser CW, Wassmann P, Reigstad M, Seuthe L (2008) Vertical flux regulation by zooplankton in the northern Barents Sea during Arctic spring. Deep Sea Res Part II 55:2320-2329

Roff JC, Taylor ME (2000) National frameworks for marine conservation-a hierarchical geophysical approach. Aquat Conserv 10:209-223

Roy V, Iken K, Archambault P (2014) Environmental drivers of the Canadian Arctic megabenthic communities. PLoS ONE 9(7):e100900. https://doi.org/10.1371/journal.pone.0100900

Rudels B, Fahrbach E, Meincke J, Budéus G, Eriksson P (2002) The East Greenland Current and its contribution to the Denmark Strait overflow. ICES J Mar Sci 59:1133-1154

Schneider W, Budéus G (1997) Summary of the Northeast Water polynya formation and development (Greenland Sea). J Mar Syst 10:107-122. https://doi.org/10.1016/S0924-7963(96)00075-9

Schulz M, Bergmann M, von Juterzenka K, Soltwedel T (2010) Colonisation of hard substrata along a channel system in the deep Greenland Sea. Polar Biol 33:1359-1369. https://doi. org/10.1007/s00300-010-0825-9

Sejr MK, Jensen KT, Rysgaard S (2000) Macrozoobenthic community structure in a high-arctic East Greenland fjord. Polar Biol 23:792-801. https://doi.org/10.1007/s003000000154

Sejr MK, Stedmon CA, Bendtsen J, Abermann J, Juul-Pedersen T, Mortensen J, Rysgaard S (2017) Evidence of local and regional freshening of Northeast Greenland coastal waters. Sci Rep 7:13183. https://doi.org/10.1038/s41598-017-10610-9

Sirenko BI (Ed) (2001) List of species of free-living invertebrates of Eurasian Arctic seas and adjacent deep waters. Russian 
Academy of Sciences, Zoological Institute, St. Petersburg, Explorations of the Fauna of the Seas 51:131

Sirenko BI (2004) Fauna and ecosystems of the Laptev Sea and adjacent deep waters of the Arctic Basin. Part II. Explorations of the fauna of the Seas. Zoological Institute RAS, St. Petersburg

Starmans A, Gutt J, Arntz WE (1999) Mega-epibenthic communities in Arctic and Antarctic shelf areas. Mar Biol 135:269-280. https://doi.org/10.1007/s002270050624

Statistics Greenland (2019) Greenland in figures 2019, 16th revised version. Greenland Statistics

Stepanjants SD (2012) Illustrated keys to free-living invertebrates of Eurasian Arctic seas and adjacent deep waters, vol 3. KMK Scientific Press Ltd, Cnidaria

Stroeve JC, Serreze MC, Holland MM, Kay JE, Malanik J, Barrett AP (2012) The Arctic's rapidly shrinking sea ice cover: a research synthesis. Clim Change 110:1005-1027. https://doi. org/10.1007/s10584-011-0101-1

Syvitski JP, Farrow GE, Atkinson RJA, Moore PG, Andrews JT (1989) Baffin Island fjord macrobenthos: bottom communities and environmental significance. Arctic 42:232-247

Taylor J, Krumpen T, Soltwedel T, Gutt J, Bergmann M (2016) Regional-and localscale variations in benthic megafaunal composition at the Arctic deep-sea observatory HAUSGARTEN. Deep Sea Res Part I 108:58-72. https://doi.org/10.1016/j. dsr.2015.12.009

Vassilenko SV, Petryashov VV (2009) Illustrated keys to free-living invertebrates of Eurasian Arctic seas and adjacent deep waters, Vol. 1. Rotifera, Pycnogonida, Cirripedia, Leptostraca, Mysidacea, Hyperiidea, Caprellidea, Euphausiasea, Dendrobranchiata, Pleocyemata, Anomura, and Brachyura. Alaska Sea Grant, University of Alaska Fairbanks

Vinogradov GM (1999) Deep-sea near-bottom swarms of pelagic amphipods Themisto: observations from submersibles. Sarsia 84:465-467

Walsh SJ, McCallum BR (1997) Performance of the Campelen 1800 shrimp trawl during the 1995 Northwest Atlantic Fisheries Centre autumn groundfish survey. Oceanogr Lit Rev 12:1539-1540

Wassmann P, Duarte CM, Agusti S, Sejr MK (2011) Footprints of climate change in the Arctic marine ecosystem. Glob Change Biol 17:1235-1249
Wassmann P, Slagstad D, Ellingsen I (2010) Primary production and climatic variability in the European sector of the Arctic Ocean prior to 2007: preliminary results. Polar Biol 33(12):1641-1650. https://doi.org/10.1007/s00300-010-0839-3

Wei CL, Rowe GT, Escobar-Briones E, Boetius A, Soltwedel T, Caley MJ, Soliman Y, Huettmann F, Qu F, Yu Z, Pitcher CR, Haedrich RL, Wicksten MK, Rex MA, Baguley JG, Sharma J, Danovaro R, MacDonald IR, Nunnally CC, Deming JW, Montagna P, Lévesque M, Weslawski JM, Włodarska-Kowalczuk M, Ingole BS, Bett BJ, Billett DSM, Yool A, Bluhm BA, Iken K, Narayanaswamy BE (2010) Global patterns and predictions of seafloor biomass using random forests. PLoS ONE 5(12):e15323

Werner I, Auel H, Garrity C, Hagen W (1999) Pelagic occurrence of the sympagic amphipod Gammarus wilkitzkii in ice-free waters of the Greenland Sea-dead end or part of life-cycle? Polar Biol 22:56-60. https://doi.org/10.1007/s003000050390

Włodarska-Kowalczuk M, Pearson T, Kendall M (2005) Benthic response to chronic natural physical disturbance by glacial sedimentation in an Arctic fjord. Mar Ecol Prog Ser 303:31-41. https ://doi.org/10.3354/meps303031

Włodarska-Kowalczuk M, Renaud PE, Węsławski JM, Cochrane SK, Denisenko SG (2012) Species diversity, functional complexity and rarity in Arctic fjordic versus open shelf benthic systems. Mar Ecol Prog Ser 463:73-87. https://doi.org/10.3354/meps0 9858

Zhulay I, Iken K, Renaud P, Bluhm BA (2019) Epifaunal community across marine landscapes of the deep Chukchi Borderland (Pacific Arctic). Deep-Sea Res PTI 151:103065

Ziegler AF, Smith CR, Edwards KF, Vernet M (2017) Glacial dropstones: islands enhancing seafloor species richness of benthic megafauna in West Antarctic Peninsula fjords. Mar Ecol Prog Ser 583:1-14. https://doi.org/10.3354/meps12363

Publisher's Note Springer Nature remains neutral with regard to jurisdictional claims in published maps and institutional affiliations. 